\title{
JOSÉ DE CAÑIZARES (1676-1750): UN PANORAMA CRÍTICO, UNA REIVINDICACIÓN LITERARIA ${ }^{1}$
}

\author{
M. ${ }^{a}$ DEL ROSARIO LEAL BONMATI \\ Universidad de Sevilla
}

\section{RESUMEN}

José de Cañizares (1676-1750), dramaturgo madrileño. Su producción es amplia, alrededor de ochenta obras, y variada en su género y temática. Se ofrecen las distintas visiones de la crítica literaria para comprobar que, en contadas ocasiones, se ha enfocado su estudio a partir de los propios textos y de las fuentes documentales; de tal manera que la percepción de la obra y la figura de Cañizares ha quedado limitada a las críticas que han ido repitiéndose a lo largo de la historia de la literatura.

Palabras clave: José de Cañizares (1676-1750) - Teatro de la primera mitad del siglo XVIII - crítica literaria.

\begin{abstract}
José de Cañizares (1676-1750), Spanish dramatist from Madrid, being his production assorted and prolific in genre and theme, with about eighty plays. It is offered different views of literary crititcism to establish that, seldom, the study of his author has been focused on starting from his own texts and documentary sources, so Cañizares' work and personality perception have been restricted to a criticisms, which have been repeated along the history of literature.
\end{abstract}

Key words: José de Cañizares (1676-1750) - Theatre First half of the XvIII century. Literary criticism.

«Adquirió [Cañizares] por espacio de medio siglo una celebridad popular de aquellas que duran en la tiniebla del error, y que luego se disminuyen o desaparecen a la luz de las mejores doctrinas» ${ }^{2}$, así enjuició Leandro Fernández de Moratín la producción de Cañizares y su gran éxito en el escenario. Ahora, casi dos siglos después, examinaremos la recepción de $\mathrm{Ca}$ ñizares e intentaremos con este trabajo despejar «las tinieblas del error» en

${ }^{1}$ Este artículo se enmarca dentro del grupo de investigación, financiado por la Junta de Andalucía «El teatro en Sevilla y su provincia» (HUM 123) y dirigido por la prof. Dña Piedad Bolaños Donoso.

${ }^{2}$ FERNÁNDEZ DE MORATÍn, Discurso preliminar, ed. 1860, p. 312-313. 
que brilló el dramaturgo y valorar si, realmente, debido a las «mejores doctrinas», quedó olvidado.

La producción de Cañizares es amplia, alrededor de ochenta comedias, y variada en su género y temática. Tradicionalmente, sus obras se han clasificado como hagiográficas, de magia, heroicas, de figurón o novelescas; zarzuelas para ser representadas en Palacio o en los corrales; sin olvidar un buen repertorio de género breve (loas, bailes, entremeses y sainetes) ${ }^{3}$. A lo largo de estas páginas, comprobaremos cómo esta rica realidad teatral atrajo a los críticos literarios de las distintas épocas y si la recepción de la figura de Cañizares se ajusta a lo que realmente supuso para su época, su público $\mathrm{y}$, en definitiva, para el teatro de principios del siglo XVIII.

\section{LA CRÍTICA ILUSTRADA}

En 1696 José de Cañizares, por primera vez, estrenó en la Corte una zarzuela: Salir el Amor al mundo, con música de Sebastián Durón, Maestro de Capilla de Carlos II; al año siguiente, el 4 de noviembre, onomástica de Carlos II, Montes afirma el desdén, zarzuela en dos jornadas, con la compañía de Juan de Cárdenas ${ }^{4}$ y en julio de 1698, vuelve a representar en Palacio Salir el amor al mundo ${ }^{5}$. Estos son los años posteriores a la disputa entre Camargo y Bances Candamo sobre la moralidad de las comedias. El primero publicó el Discurso theologico sobre los teatros y comedias de este siglo $(1690)^{6}$ y Bances salió al paso con su obra Theatro de los theatros de los passados y presentes siglos (1690?). Según el dramaturgo asturiano, las comedias de la Corte no podían ni ser juzgadas ni rechazadas «porque festejar a los Reyes es arte aúlica y política no poco dificultosa y no tienen aquellas obras censura alguna antes de ejecutarse» ${ }^{7}$; así, las primeras obras de Cañizares quedaban justificadas y ratificadas por estas palabras y por su éxito inmediato: las «comedias en música» y su puesta en escena agradaron en Palacio, como testimonian las zarzuelas que estrenó en años consecutivos ${ }^{8}$.

A medida que avanza la primera y segunda década del siglo, continúan en cartel las obras de los dramaturgos del Siglo de Oro, a la vez que van ganando terreno las comedias, llamadas de «teatro», de magia y las zarzuelas en los corrales de Madrid, donde Cañizares juega un papel protagonista 9 .

${ }^{3}$ MERIMÉE, 1983, pp. 81-142.

${ }^{4}$ Fuentes VI, p. 298 y Fuentes IX, p. 165

${ }^{5}$ Fuentes IX, p. 208.

${ }^{6}$ Esta fecha es, dentro de las posibilidades, la más probable, según señala Duncan W. Moir (Teatro..., ed. 1970, p. XXXIX).

${ }^{7}$ Idem, p. 93.

${ }^{8}$ LEAL, 2006, pp. 470-472.

9 ANDIOC, 1987, pp.14-15; pp. 33 y ss. 
El estilo de esta cultura literaria no queda plasmado en la crítica del momento, prácticamente, hasta La Oración en alabanza de las obras de Don Diego Saavedra Fajardo (1725), Oración que exhorta a seguir la verdadera idea de la elocuencia española (1727) de Mayans y Siscar y El Teatro crítico (1726) de Feijoo en donde se aprecia la preocupación por la lengua y el estilo barroco desvirtuado que primaba en la literatura del momento. La publicación de estas obras coincide con el término de la primera crisis de la conciencia española, donde aún continua la inercia del ambiente cultural del siglo XVII en las letras pero no así en las ciencias ${ }^{10}$. En sus escritos, el valenciano Mayans entra a juzgar la elocuencia y en base a ella, sin entrar a valorar los autores vivos ${ }^{11}$, sopesa el arte de la escritura de nuestros clásicos y marca unas pautas comunes:

«Acaudalad en la memoria un aparato riquísimo de palabras y frases propias, trasponiéndolas tal vez decentemente. Pensad con solidez y discreción. Añadid razones al discurso, viveza en las sentencias, propiedad y claridad en el decir, elegancia y número a la oración» ${ }^{12}$.

La elocuencia remite a un lenguaje claro, con palabras apropiadas, naturales; en definitiva, un discurso coherente, y no aquella forma de expresión oscura y recargada producida por los epígonos barroquizantes y por el Barroco mismo ${ }^{13}$. Estos escritos mayansianos son las primeras protestas contra este estilo vacío y recargado ${ }^{14}$.

Feijoo publica su Teatro crítico coetáneamente a la producción de Mayans. En el campo de la creación literaria y del arte, el benedictino carecía de experiencias estéticas y nunca había asistido a una representación teatral ${ }^{15}$. A lo largo de su obra, se advierte que apoya el teatro nacional, identificándolo con el popular, aunque a veces lo percibía como un foco difusor de historias no muy verdaderas que fomentaban la creencia en ellas, como se lee en el discurso sobre la «Fábula del establecimiento de la Inquisición en Portugal»:

Lo que parece dio tanto curso a esta patraña entre los españoles fue una comedia de autor incierto (un ingenio de esta Corte) ${ }^{16}$ intitulada El falso Nuncio de Portugal, donde circunstancia más o menos, está vertida la historia que acabamos de referir [...]. Lo que hizo el autor de la comedia fue propagar la noticia

\footnotetext{
10 Abellán, vol. III, 1981, p. 284.

11 MAYANS I SISCAR, Oración que exhorta a seguir..., s.a, p. 7.

12 Idem, p. 33.

13 PÉReZ Magallón, 1991, p. 90 y 113.

14 MAYANS I SISCAR, Oración que exhorta a seguir...en: Obras completas, vol. II, 1984, p. 3

15 FERNÁNDEZ Y GONZÁLEZ, 1964, p. 22.

${ }^{16}$ El ingenio es Cañizares y la obra se terminó de escribir en 1706 (Fuentes XVI, p. 129).
} 
de modo que se extendiese a todo género de gentes; porque no hay medio tan eficaz para vulgarizar una historia como plantarla en solfa en una comedia ${ }^{17}$.

Según Feijoo, el acierto en la composición literaria no depende de las reglas, ni radica en que se ajuste el texto a las normas dictadas para determinado género literario sino que le daba más importancia a la libertad de estilo y de composición ${ }^{18}$.

Una década más tarde de la publicación del Teatro Crítico, y con la pluma de Cañizares a pleno rendimiento, ve la luz la primera edición de $L a$ Poética (1737) de Luzán. En ella se encuentra la primera valoración positiva sobre nuestro autor, aunque también destaca algunos defectos en la composición de sus obras:

Don José de Cañizares, tomando con prudente acuerdo una derrota más propia de la poesía cómica que otros siguieron, ha escrito muchas obras de singular aplauso. En El dómine Lucas, en El músico por amor, y en otras, he visto con particular gusto costumbres bien pintadas y mantenidas hasta el fin, asuntos y estilos propios de comedia, graciosidad en la acción misma y en las personas principales [...], circunstancias todas muy apreciables y que he buscado en vano en otros cómicos. Supuesto, pues, el mérito singular de éstos y de otros poetas y supuesta la estimación y el aprecio que yo hago de sus aciertos, no tendrán razón sus apasionados de extrañar ni ofenderse de que me detenga a notar aquí algunos de sus efectos y descuidos para instrucción de los que en adelante escribieren $^{19}$.

El crítico aragonés resalta la construcción de los personajes y su evolución; cómo se reflejan muy bien las costumbres que, según los preceptos clásicos, es aquello que se exige a una comedia; los temas elegidos y su gran capacidad para conectar con el público. Asistimos a la primera reacción neoclásica ponderada que valora los logros y defectos del teatro inmediatamente anterior; pero, a la vez, no se hace esperar una reacción tradicionalista que considera a los «nuevos» dramaturgos como continuadores e imitadores de escasa fortuna del gran teatro del Siglo de Oro y que, por supuesto, no están a la altura de un Lope, Moreto, Calderón o Rojas. La crítica de los tradicionalistas estalla a través del medio de difusión del momento: el periódico. El Diario de los Literatos de España publica la Sátira contra los malos escritores de este siglo, de Jorge Pitillas ${ }^{20}$ en 1742, y en el prólogo resalta su originalidad: «causará precisamente extrañeza a todos porque siendo éste el único papel en su género, que en nuestros tiempos se ha dejado de ver en España, es consiguiente que una cosa tan absolutamente nueva, sea recibida

\footnotetext{
${ }^{17}$ FeIJOO, Teatro crítico, vol. IV, ed. 1961, p. 300.

18 FERNÁNDEZ Y GONZÁLEZ, 1964, pp. 27-28.

19 LUZÁn, Poética, ed. 1977, pp. 538-539.

${ }^{20}$ Jorge Pitillas es seudónimo del Licenciado José Gerardo de Hervás (Cueto, vol. I, 1869, p. 87).
} 
con maravilla universal» ${ }^{21}$. Se arroga la condición de ser el primero que satiriza la forma de escribir de los nuevos escritores y así se dirige al «nuevo escritor»:

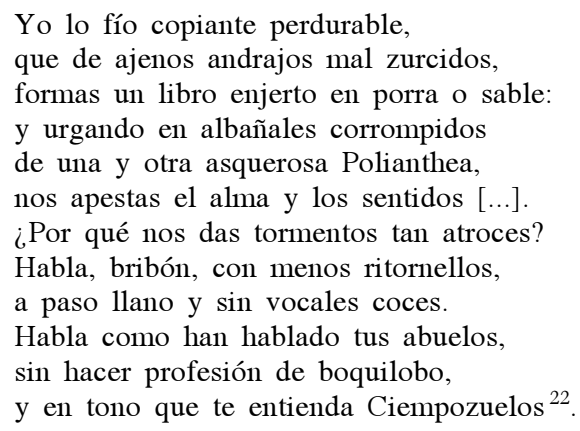

Rechaza la composición de obras literarias a partir de la suma indiscriminada de citas y situaciones recogidas en las polianteas, la mezcla del español con palabras extranjeras - francesas o italianas- que impiden al público conocer el contenido, e incluso, el tono empleado de voz, imitando a los foráneos; con esta última crítica quizás, podría aludir al tono particular de la lengua predominante en la corte, el francés. A nuestro dramaturgo lo critica con una ironía fuerte y barata ya que es el representante más destacado de los «nuevos autores»: «en versos tan malditos y endiablados /como pudiera el mismo Cañizares» ${ }^{23}$.

Tampoco se librará el veterano coracero de las diatribas de Maruján, poeta con el que mantuvo una polémica casi personal y que, precisamente, inaugura la faceta de un Cañizares imitador y falsificador de comedias del Siglo de Oro:

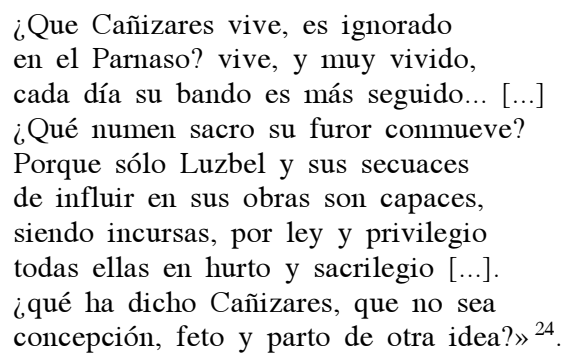

${ }^{21}$ Idem, pp.196-197. Aquí palpamos la escasez de escritos sobre el teatro y que si Pitillas hubiera vivido unos años más (murió pocos meses después de publicar la Sátira), hubiera visto cómo se multiplicaban. (Cueto, vol I, 1869, p. 87).

${ }^{22}$ PITILlas, Sátira..., p. 207.

${ }^{23}$ Idem, p. 210.

${ }^{24}$ Recogido por Cayetano Alberto de la Barrera en Cueto, vol. I, 1869, p. C, n.1. 
A los siete años de la publicación del texto de Pitillas, publica Nasarre su Disertación o Prólogo sobre las comedias de España (1749). Elabora la historia de la comedia española en la que Lope y Calderón son los verdaderos corruptores del teatro español; antes de Lope, las comedias eran perfectas ${ }^{25}$; por esta razón, ni siquiera menciona a Cañizares:

Tenemos ciertamente muchas piezas de teatro escritas con todo el arte, con caracteres naturales y propios, con buena moral, con maraña y enredo verosímil, con las unidades tan apetecidas y decantadas, con dicción hermosa y correspondiente, y que agradan, divierten e instruyen al vulgo y a los cortesanos (...); pero no hay que buscar estas comedias entre las de Lope de Vega, ni las de don Pedro Calderón, ni de otros que los imitaron ${ }^{26}$.

Las respuestas a una crítica tan severa no se hicieron esperar desde Montiano, Moratín padre, Estala hasta críticos del siglo $\mathrm{XX}^{27}$. Un juicio destacado del siglo XVIII es el de Tomás de Erauso y Zabaleta con su Discurso crítico sobre el origen, calidad, y estado presente de las comedias de Espa$\tilde{n} a(1750)^{28}$, que busca revalorizar a los autores del Siglo de Oro en aquello donde brilla su genio y no en sus carencias ${ }^{29}$.

La polémica empieza a cobrar más intensidad con las obras de Nicolás Fernández de Moratín. En 1762 publica los Desengaños donde critica la dramaturgia de Lope y Calderón, pero no su genio. Su postura es reformista, manteniéndose en la linea de acercamiento a los autores del siglo XVII y de principios del siglo XVIII:

Y una obra de arte es lo mismo que decir una obra buena; y siendo así, no puede menos que agradar y se experimenta en las comedias más arregladas, y así habrá visto usted cuán gustoso está el pueblo viendo representar un carácter bien sostenido como en El dómine Lucas, El músico por amor, El labrador Juan Pascual, El amor al uso, Don Lucas del Cigarral, Cuál es mayor perfección, El hechizado por fuerza, Don Domingo de don Blas, El castigo en la miseria [...]. No obstante que no carecen de algunas faltas que se disminuyen por los grandes primores que abundan ${ }^{30}$.

Las obras citadas, de gusto popular —entre ellas, las dos primeras pertenecen a Cañizares-, tienen ciertas reglas que vienen de la misma naturaleza (son «arregladas») y, por eso, agradan tanto, aunque esto no las eximan de algunos fallos. Esta predisposición de los neoclásicos hacia nuestro dramaturgo se observa a nivel oficial cuando el Conde Aranda pide en 1767 a Bernardo de Iriarte que elabore una relación de comedias barrocas que se

\footnotetext{
${ }_{25}$ NASARRE, Disertación, ed. 1992, p. 21.

${ }^{26}$ Idem, p. 80.

${ }^{27}$ Idem, p. 24-29.

${ }^{28}$ La edición del texto la citaré por La crítica dramática..., 2000, pp. 88-90.

${ }^{29}$ Idem, p. 88.

${ }^{30}$ FERNÁNDEZ DE MORATín, Desengaños, ed. 1996, p. 153-154.
} 
pudieran reformar o que ofrecieran menos desajustes. El ilustrado Iriarte presenta, aparte de otras obras, tres de Cañizares: El Gran Tacaño, El Dómine Lucas y El Montañés en la corte ${ }^{31}$. En poco tiempo se ha evolucionado desde una crítica literaria basada en la dramaturgia áurea a una visión desde las reglas neoclásicas; y a partir de esta petición del Conde de Aranda, la crítica literaria y el afán reformista se unen en la valoración de Cañizares.

Hasta 1789, año de la segunda edición de La Poética de Luzán, no volvemos a encontrar una crítica seria, contemporánea y de un gusto contrario al de nuestro autor:

Don José de Cañizares, casi contemporáneo nuestro, hizo El dómine Lucas y otras comedias de carácter, que le dieron reputación. No diré que en estas comedias falte qué corregir, ni que contienen todas las circunstancias constitutivas de la perfección; pero van camino de ella, y tienen mucho de lo que llamaban los antiguos vis comica [...]. Con Cañizares desaparecieron nuestros poetas cómicos; pues desde que él faltó, no conozco alguno que merezca nombrarse ${ }^{32}$.

Luzán incide únicamente en las comedias de figurón porque, en palabras del profesor M. Vitse, constituyen un «avance importante, aunque limitado, hacia el modelo ideal de comedia cómica clásica» ${ }^{33}$; así, se comprende el aprecio de Luzán y que, incluso, los considere como el último poeta cómico, después de Calderón.

En los años finales del siglo XVIII asistimos a la aparición de nuevos textos sobre el teatro que, en algunos casos, vuelven a repetir las ideas ya divulgadas sobre las buenas comedias, como hace Quintana en 1791 con Las reglas del drama ${ }^{34}$, imbuidas de L'art poetique de Boileau, donde sólo trata de Lope y Calderón, sin descender a otros autores.

Entre 1792 y 1793 Forner publica Las Exequias de la lengua castellana. Sátira menipea ${ }^{35}$. Recordemos su argumento: de una forma imaginaria y simbólica, Aminta y su amigo Arcadio ${ }^{36}$ viajan al Parnaso, invitados por Apolo a asistir a las honras fúnebres de la Lengua Castellana. Cervantes será el guía de los dos amigos. Durante su paseo por el Parnaso se encuentran con distintos autores, periodistas y poetas. Hacia el final del viaje y poco antes del funeral, aparecerá el Conde Fernán Núñez que les acompañará en los últimos diálogos, precisamente con Feijoo y Cañizares ${ }^{37}$. Éste es elegido como el

\footnotetext{
31 PALACIOS, 1990, pp. 45 y 62.

32 LUZÁN, ed. 1977, pp.407-408.

33 1986, p. 383.

${ }^{34}$ QUINTANA, ed. 1852, pp. 75-83

35 FORNER, Exequias, ed. 2003.

${ }^{36}$ Ambos nombres corresponden a Forner y a su amigo Iglesias de la Casa, respectivamente (Idem, p. xlvii).

37 Interesa resaltar la personalidad de los personajes citados: Francisco Gutiérrez de los Ríos y Córdoba, Conde Fernán Núñez escribió hacia 1680 El hombre práctico o Discursos varios sobre su conocimiento y enseñanza: (Introducción, edición y notas de Jesús
} 
autor dramático más representativo del teatro del momento, por el que Forner puede expresar sus reflexiones acerca del teatro en España ${ }^{38} \mathrm{y}$, además, provoca que el propio personaje se autocritique y, a la vez, se alaben las estructuras de sus comedias:

Que habiendo yo nacido para aumentar el escaso número de las buenas comedias, por haber vivido en una edad estragada absolutamente en el conocimiento y práctica del buen gusto, no hice más que disparatar con seso y ganar nombre de grande ingenio, sí, pero desatinado. Sin embargo - le dijo el conde- debéis consolaros con que, en la labor confusa de vuestros dramas, engastasteis a veces varias escenas que harán disculpables vuestros desaciertos; porque ellas fueron hijas de la grandeza de vuestro genio y estos procedieron de la obscuridad y depravación del siglo en que florecisteis ${ }^{39}$.

De nuevo, Cañizares es adscrito temporalmente a la estética dramática del siglo XVII, aunque se le valora positivamente su genio, su capacidad de crear escenas memorables, más ajustadas al «buen gsuto». Al final de la conversación, Cervantes sentencia, haciendo una advertencia a los neoclásicos y disculpando a Cañizares:

Vos, amigo mío, labrasteis monstruos; pero monstruos muy agradables y muy llenos de vida. Y ved aquí por qué el pueblo prefiere vuestra vivísima irregularidad a la regularidad cadavérica de algunos que hoy se jactan de reformadores $^{40}$.

Este juicio es el único que contrapone la realidad vivida por el público ante una obra de Cañizares o de los reformistas; de hecho, en los años que escribe Forner, las comedias más aplaudidas fueron Juana, la Rabicortona; A un tiempo esclavo y señor y mágico africano y Marta la Romarantina, ésta última de Cañizares ${ }^{41}$. Poco tiempo después, Forner volverá a proponer su visión del teatro en Sevilla en la famosa Introducción o Loa a la apertura del teatro ${ }^{42}$ que después, será contestada con una Anti-Loa ${ }^{43}$, criticando a nuestro dramaturgo desde el punto de vista moral o de costumbres:

Pérez Magallón y Russell P. Sebold, 2000), y es considerado como uno de los novatores; Fr. Benito Feijoo fue el primero que comenzó a criticar de forma racional y Cañizares es el autor teatral con mayor prestigio de finales del s. XVII y principios del s. XVIII: Forner reúne en esta conversación a tres personajes coetáneos y que vivieron de forma personal la transición del s. XVII al s. XVIII. Es muy interesante la visión que aquí nos ofrece Forner ya que nos hace comprender la visión que los neoclásicos tenían de sus inmediatos antecesores.

${ }^{38}$ FORNER, Exequias, ed. 2003, pp.196-221.

${ }^{39}$ Idem, p. 201.

${ }^{40}$ Idem, p. 220.

${ }^{41}$ ANDIOC, 1987, p. 39.

${ }^{42}$ Manifiestos de don Juan Pablo Forner, vol. V, ¿1796?, pp. 26-55, BN, Ms. 9586.

${ }^{43}$ Anti-Loa para la cerradura del teatro de Sevilla su autor D.JIP.F.F. Agradezco a la prof. Dña. Piedad Bolaños que me haya facilitado consultar el texto de este interesante manuscrito, del que ella está realizando una edición crítica. 


$\begin{array}{ll}\text { Narciso. } & \text { «Con que un sentir os concuerda, } \\ & \text { unánime confesais } \\ & \text { que las ingeniosas piezas } \\ & \text { de Calderón, de Monroy, } \\ & \text { de Cañizares, et cetera } \\ & \text { dañan a nuestras costumbres. } \\ \text { Forner. } & \text { Así confesarlo es fuerza, } \\ & \text { en virtud de haberlo escrito } \\ & \text { y haberlo dado a la prensa» }{ }^{44} \text {. }\end{array}$

No podemos olvidar la postura del escolapio Pedro Estala, amigo de Forner, que compartió muchas veladas literarias con él en Madrid y también, en este caso, las posturas sobre el teatro de principios de siglo que expuso en su Discurso sobre la comedia antigua y moderna (1794). Analiza la evolución del género desde los griegos hasta su época; respecto al teatro del Siglo de Oro, hace un análisis, «ejemplo de ecuanimidad y buen criterio, punto de encuentro entre las opiniones de los polemistas «patriotas» y de los estrictos defensores de las unidades y de las normas pretendidamente clásicas» ${ }^{45} \mathrm{y}$, al final, reconoce el talento de Cañizares para las comedias de figurón:

Algunas comedias bastantes agradables de Cañizares como son El Dómine Lucas, El Montañés en la Corte, El honor da entendimiento, etc. bien que tienen defectos muy considerables. Uno de estos es que sus caracteres ridículos son más propios de la farsa que de la comedia fina, pues no se hallan en la naturaleza y únicamente sirven para hacer reír ${ }^{46}$.

Hacia 1827, Martínez de la Rosa en su Apéndice sobre la comedia española, valora su prolífica produccióN; aunque también achaca sus errores a la época que le tocó vivir, al igual que Forner:

Tal fue Cañizares, con muchos alientos de dramático, y con escasa prudencia para templarlos y dirigirlos, echóse a delirar ese poeta, tentando todos los caminos y presentando en la escena argumentos de todo jaez, por disparatados que fuesen: comedias de teatro, de vidas de santos, de historia, zarzuelas, tragedias, comedias de figurón [...]. De creer es que Cañizares hubiera sobresalido mucho más en la carrera cómica si le hubiese deparado la suerte alcanzar mejores tiempos ${ }^{47}$.

Finalmente, llegamos a la publicación de Los orígenes del teatro y $E l$ Discurso preliminar (1830) de Leandro Fernández de Moratín, que le reconoce su vena dramática para componer y adaptar otras obras; pero sin capacidad creativa propia:

44 Idem, fol. 9r ${ }^{\circ}$.

45 CHECA BELTRÁN, 1990, p. 28

46 ARENAS, 2003, p. 389. El citado libro aporta mucho sobre la figura de Estala y sus contemporáneos, además de hacer un estudio de sus principales obras. Para consultar la vida social y literaria de Forner y Estala, véanse las pp. 36-46.

${ }^{47}$ MARTÍnEZ DE LA ROSA, ed. 1962, p. 253. 


\begin{abstract}
No tuvo talento inventor; pero llegó a suplir esta falta con una particular habilidad que manifestó para saber introducir en sus fábulas cuanto había leído en las otras: este fue su mayor estudio. Apenas se hallará en sus comedias una situación de algún interés, sin que fácilmente pueda indicarse el autor de quien la tomó [...]. Cañizares tuvo presentes las mejores piezas francesas e italianas que se habían publicado en su tiempo; pero no conoció su mérito, y precisamente las imitaciones que hizo de ellas son lo peor de cuanto escribía para el teatro ${ }^{48}$.
\end{abstract}

En este fragmento hace alusión a su mala fama como copista e imitador y es el primero que le atribuye el afán por divulgar el teatro francés e italiano; respecto a esta cuestión, está haciendo clara referencia a El sacrificio de Ifigenia, imitación de la obra de Racine y No hay con la patria venganza y Temístocles de Persia, basada en la ópera homónima de Metastasio; pero más adelante le reconoce cierto talento para escribir comedias de figurón y las novelescas:

Si se consideran únicamente aquellas en que más se acercó a la buena comedia, no es posible disimular que en las de figurón excedió los límites de lo verosímil, recargó los caracteres, mezcló muchas gracias y situaciones verdaderamente cómicas con infinitas chocarrerías, y a cada paso adoptó los recursos de la farsa grosera [...]. En las que se propuso por objeto una pasión amorosa, valiéndose de anécdotas y personajes históricos [...], la composición de la fábula no es intrincada ni fatigosa; y con la mucha práctica y facilidad que tenía el autor para los versos octosilábicos, introdujo escenas de estilo florido y conceptuoso, no distante de los originales que imitaba, y siempre agradable a la multitud que oye y no examina ${ }^{49}$.

Escasa creatividad, imitador sin arte, caracteres mal construidos, cierta buena estructuración de las comedias, fuerza cómica y un tiempo equivocado para escribir sus comedias es la visión de Cañizares que nos ofrece la crítica neoclásica. Si la comparamos con la de los primeros años del siglo, se observa una tendencia más rigorista en la aplicación de los preceptos neoclásicos. Valgan como conclusión estas palabras de Moratín:

Cañizares escribía sin conocimiento de los preceptos poéticos: su abundante vena le adquirió por espacio de medio siglo una celebridad popular de aquellas que duran en la tiniebla del error, y que luego se disminuyen o desaparecen a la luz de las mejores doctrinas ${ }^{50}$

Tendremos que esperar al paso del tiempo para verificar esta opinión y con esta perspectiva nos adentraremos en el periodo romántico, aunque antes nos detendremos a considerar cómo se divulgó la fama de nuestro dramaturgo.

\footnotetext{
${ }^{48}$ FERNÁNDEZ DE MORATín, Discurso preliminar, ed. 1860, p. 312.

${ }^{49}$ Idem, p. 312.

${ }^{50}$ Idem, p. 312-313.
} 


\subsection{La opinión pública sobre Cañizares}

Poéticas, prólogos, desengaños... Todos los géneros son válidos para verter opiniones sobre el teatro: desde el nivel más especulativo y teórico como la Poética de Luzán, pasamos al terreno más práctico, que desciende al mundo real de la representación, donde nos encontramos con la sátira paródica de Iriarte, Los literatos en Cuaresma (1773). En ella ironiza sobre las expectativas del público en el teatro y que Iriarte lo identifica con los males que sufre la escena española: comedias escritas a imitación de novelas, enormes desajustes de lugar, tiempo y espacio, cómicos que actúan de forma afectada, que no declaman bien y grandes cambios de escena y aparatos ${ }^{51}$; en 1782 , Leandro Fernández de Moratín continúa el género con una «Sátira contra los vicios introducidos en la poesía castellana» y, básicamente, los reduce a la pérdida de los modelos clásicos de la antigüedad:

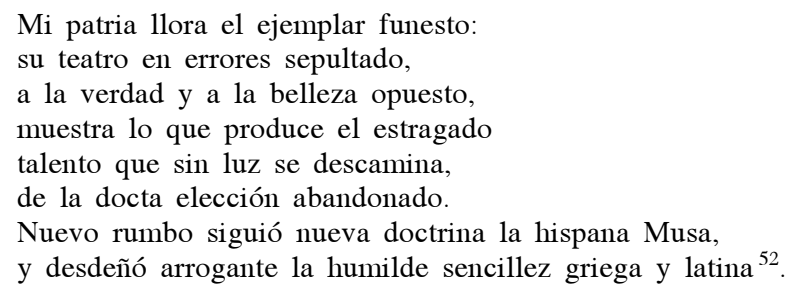

Los periódicos no se mantuvieron al margen de la polémica; o bien difundieron solamente las obras más clasicistas francesas o italianas, como sucede en El Mercurio histórico y político ${ }^{53}$, donde no se tiene noticia de obras impresas y/o representadas de Cañizares o bien cargaron las tintas sobre la puesta en escena en los corrales, como se lee en los discursos XCII y XCIII de El Censor (1781-1787) ${ }^{54}$.

La repercusión de los teóricos del teatro se hace notar pronto en otras ramas del saber. En 1790 Álvarez de Baena, historiador, al relatar la vida del dramaturgo, ofrece la visión de Luzán de un Cañizares más diestro en las comedias de figurón:

Escribió muchas comedias y todas fueron bien recibidas del público, y mucho más de los representantes, a quienes dieron y dan mucho dinero. Las de carácter o figurón deben apreciarse más que las otras [...] El autor tenía particular talento para ellas, usando del llano estilo que les conviene, y elevándolo en las piezas serias le echó a perder, dando en el vicio de culto ${ }^{55}$.

51 IRIARTE, Los literatos en Cuaresma, ed. 2005, pp.176-203.

52 FERNÁNDEZ DE MORATÍN, «Sátira...», ed. 1857, p. 579.

53 Por ejemplo, en hace alusión a la ópera Artajerjes de Metastasio (III'1738, pp. 87 88); a la tragedia Atalía de Racine (VIII'1739, p. 57 y ss).

${ }^{54}$ «El Censor»(1781-1782), ed. 1972, pp. 167-190.

55 ÁlvareZ de BAENA, vol. III, 1790, p.70. 
También se recoge la opinión difundida de sus adaptaciones e imitaciones; como, por ejemplo, en el suceso recogido por Casiano Pellicer: sugiere que nuestro autor plasmó en El montañés en la Corte el carácter de José Miravet y la anécdota de la golilla ${ }^{56}$, o bien respecto a las zarzuelas, no deja de llamar la atención que sea un comediante, García Villanueva, el que haga mención de ellas:

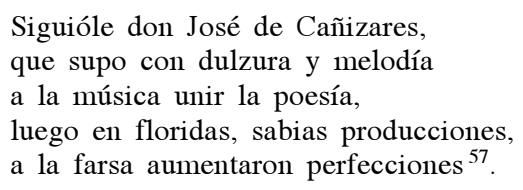

Estas opiniones que abarcan un campo más amplio que el del público de un corral, de palacio, de algunas tertulias de reformadores o escritos teóricos de los dramaturgos, llegan a crear opinión sobre el teatro de Cañizares $\mathrm{y}$, precisamente, algunos de estos escritos de carácter más divugativo hacen referencia a un aspecto que apenas tocan los eruditos: la zarzuela. También tendremos que tener en cuenta que el mismo teatro sirve de altavoz a las propias obras de Cañizares, después de su fallecimiento. Ramón de la Cruz escribe un sainete llamado La comedia de Valmojado en el que ridiculiza la adaptación de Cañizares de la Ifigenia de Racine, como hace notar Díez Regañón ${ }^{58}$ o también pone en escena Marta abandonada y Carnaval de París ${ }^{59}$, basándose en la comedia de magia Marta la Romarantina, y López de Sedano hace lo mismo con su comedia Marta aparente ${ }^{60}$.

\section{UNA VISIÓN ROMÁNTICA}

Los primeros intentos de adoptar en la crítica española las nuevas ideas estéticas promovidas por los hermanos Schlegel ${ }^{61}$, quedaron reducidos a la

${ }^{56}$ El citado Miravet servía a un caballero en Madrid. Una vez se presentó sin golilla ante su amo y éste le riñó mucho. El caballero le ordenó que debía ponérsela aunque fuera en camisa y así se presentó una noche que hubo ladrones. En la obra de Cañizares, es el criado Martínez quien aparece así ante doña Menda e Inés, al final de la segunda jornada. (Tratado histórico..., vol.II, 1804, pp. 60-61).

${ }^{57}$ GaRCía DE VILlanUeVA, Origen y épocas..., 1804, pp. XXII-XXIII.

${ }^{58}$ «Y grata fue mi sorpresa cuando, después de leídas unas cuantas páginas, pude cerciorarme de que se trataba de una parodia de Ifigenia en Áulida, pero no la de Eurípides, sino la de la absurda refundición que de ella hizo Cañizares» (1957, p. 297).

${ }^{59}$ Representada en el Carnaval de 1762. (ed. 1984, p. 14).

${ }^{60}$ LÓPEZ DE SEDANO, Marta aparente, ed. 1984.

${ }^{61}$ Las lecciones de Alfred W. Schlegel fueron recogidas en Cours de littérature dramatique, traducido por Necker de Saussure, Paris, Lacroix Verboeckhoven, 1865 y también tuvieron una larga repercusión la Historia de la literatura antigua y moderna y La Historia de la literatura europea, ambos libros de Friederich Schlegel; parte de los 
controversia entre Nicolás Bolh de Faber, defensor de las nuevas ideas, y José Joaquín de Mora ${ }^{62}$. No llegó a calar entre los críticos la postura romántica y se diluyó hasta que Agustín Durán escribió El Discurso sobre el influjo que ha tenido la crítica moderna en la decadencia del Teatro antiguo español (1828), donde sí podremos comprobar la influencia de los Schlegel y, en consecuencia, así define Durán el arte dramático: «el teatro debe ser en cada país la expresión poética e ideal de sus necesidades morales, y de los goces adecuados a la manera de existir, sentir y juzgar de sus habitantes» ${ }^{63}$. Según estas palabras, la comedia es expresión del genio de cada pueblo, por lo tanto, el teatro del Siglo de Oro corresponde al genio español, pero en su evolución al final del siglo XVII, Durán entiende que se ha degradado, mientras en Francia brilla la «perfección» clásica ${ }^{64}$ :

Desde Lope de Vega a Calderón fue cada día perfeccionándose y aumentándose el brillo de nuestro drama. Las glorias patrias, los triunfos de sus guerreros, los de sus héroes cristianos, el amor delicado y caballeroso, el punto de honor y los celos, todo se refería, se cantaba y ponía en acción sobre la escena nacional, que conservó todas sus bellezas y superioridad hasta fines del mismo siglo [...] .A tal grado de perfección había llegado ésta [Francia] en el género dramático que adoptó para sí [el griego clásico] cuando en la misma época, olvidándose la España del que le era propio, sustituía al colmo de bellezas que le adornaban, aquel gusto mezquino y depravado, que degradó nuestra escena desde fines del siglo XVII hasta mediados del XVIII. Todos los ramos de la literatura experimentaron en nuestro país, igualmente que la dramática, la vándala incursión de los gongoristas y conceptistas ${ }^{65}$.

El teatro de la primera mitad del siglo XVIII ha desembocado en puro conceptismo y en un barroco degenerado que no reflejaría el genio nacional y, en consecuencia, los autores de los primeros años del Setecientos tampoco serían los adalides del verdadero espíritu español y nuestra literatura estuvo «abandonada largo tiempo a los extravíos del mal gusto, no halló siquiera una benéfica mano para ayudarla a salir del caos y degradación donde los conceptistas la habían sumergido» ${ }^{66}$. Por estos dos últimos párrafos transcritos, cabe pensar que Cañizares se encuadraría, por el arco temporal, dentro de ese ambiente conceptista y caótico al que se hace referencia; sin embargo, no es considerado así en el núcleo de los escritos de Lista, Hartzenbusch y Mesonero Romanos.

mismos estén recogidos en Obras selectas, edición, introducción y notas de Hans Juretsche, traducción de Miguel Ángel Vega Cernuda, 2 vols. Madrid, Fundación Universitaria Española, 1983.

${ }^{62}$ Crítica dramática..., 2000, p.25-26. Resume y aclara esta polémica.

${ }^{63}$ DURÁn, ed. 1994, p. 53.

${ }^{64}$ Idem, pp. 48- 49.

${ }^{65}$ Idem, pp. 48- 49.

${ }^{66}$ Idem, p. 50. 
Después de Cañizares se escribieron algunas comedias en el género de Calderón; mas ninguna de ellas ha tenido aceptación o fama en el teatro. Empezaron por una parte los partidarios de Racine y Moliere a desacreditar el género; por otra, a corromper la escena con sus composiciones estrambóticas los Zavalas, Comellas y Trigueros, mientras adormecían el auditorio Luyando y Moratín padre [...]. Por todas estas razones debe mirarse a Cañizares como el último poeta cómico del teatro español que empezó en Lope de Vega. [...] Algunos quieren que se le considere como eslabón intermedio que sirvió para unir el género de Calderón con el que se adopté imitado del teatro francés; y se fundan en el conato que puso en describir caracteres, que mejor pudieran llamarse caricaturas. Nosotros no lo creemos así, y tenemos a Cañizares por calderoniano puro ${ }^{67}$.

Lista realza a nuestro dramaturgo en el panorama teatral —nada halagüeño porque las tablas estaban invadidas de obras francesas y españolas llenas de irregularidades y de asunto estrafalario-; de tal manera que afirma rotundamente su condición de «calderoniano puro».

Para Hartzenbusch, es el primer autor dramático del siglo XVIII que se propuso imitar la dramaturgia francesa cuando escogió como modelo $E l$ sacrificio de Ifigenia de Racine $\mathrm{y}$, juzga así el resultado:

Cañizares, poeta cómico en segunda linea, precisado a apartarse de Racine, porque el gusto clásico no es el nuestro, produjo sin embargo, una obra en que hay caracteres, interés y aún grandeza; por lo cual se ha sostenido brillantemente en la escena hasta principios de nuestro siglo: hacer esto no es poco. Lo bueno o mediano que hay en la comedia española es de Cañizares, es nuestro: mucho, muchísimo de lo bueno que tiene la tragedia de Racine, pertenece exclusivamente al ingenio de Eurípides ${ }^{68}$.

Reconoce más el mérito de Eurípides que de Racine: intenta dejar claro que la imitación no es del francés sino del griego. También da su parecer sobre la reforma de Moratín, enmarcándola en su tiempo, de esta forma, intentaba redimensionar el afán de renovación en el teatro del siglo XVIII:

Yo creo que Moratín conocería el mérito de las comedias de Aristófanes, y sin embargo, escribió las suyas con arreglo a otro gusto: lo que no conoció Cañizares fue que el teatro español necesitaba reforma, y que él debería empezarla: no una reforma como la quería Moratín; pero sí como el buen gusto reclamaba ${ }^{69}$.

Para estos autores, Cañizares pertenece a la escuela de Calderón, responde al genio nacional. Los críticos románticos tenían la intención de hacer valer ante Europa que, a principios del siglo XVIII, aún existía un teatro propio del país, sin intentos de imitar otro arte teatral europeo. Así se entiende que «la crítica literaria del siglo XIX vinculó casi sin discusión el teatro barroco español a la idiosincrasia nacional, así como al comienzo de

\footnotetext{
${ }^{67}$ LISTA, 1844, p. 212.

68 HARTZENBUSCH, 1856, p.68.

${ }^{69}$ Idem, 1845 , p. 383.
} 
la era cristiana y al desenvolvimiento de la modernidad» ${ }^{70}$ y que ésta no tuviera en cuenta los fallos que los neoclásicos denunciaron. En general, los románticos son más benévolos en su crítica, como por ejemplo, la realizada por Hartzenbusch al estudiar el Temístocles de Metastasio y la obra homónima que compuso Cañizares ${ }^{71}$.

Mesonero Romanos analiza las obras de nuestro autor de una manera más amplia y, a la vez, lo encuadra mejor en su época - debido al mismo carácter general de su Introducción a los dramáticos posteriores a Lope de Vega, recogida en la Biblioteca de Autores Españoles- y lo dota de cierto halo positivo y de buen hacer, propio de los románticos:

Don José de Cañizares es el otro poeta dramático que, juntamente con Zamora, cultivó todavía hasta bien entrado el siglo último la escuela del antiguo teatro español, y la cultivó con tanto mayor éxito, cuanto indudablemente sobrepujaba a aquel en prendas de invención, ingenio y agudeza. La fecundidad por otro lado de su numen poético, y que sólo conoce rival entre los primeros dramaturgos del XVII, le permitió producir casi un centenar de piezas, y la brillantez de su imaginación, la variedad de su gusto, y el estudio que había hecho ya de los recientes modelos de la escuela francesa, le dieron motivo para poder imitarlos a todos alternativamente, muchas veces con tan buen resultado, que pudieran equivocarse sus obras con las mismas de sus modelos ${ }^{72}$.

Buen imitador de las obras francesas, con imaginación, muy prolífico, y lo equipara a los primeros dramaturgos del siglo XVII. No se puede negar que Mesonero peca de exageración a la hora de valorar las imitaciones; y al final de su escrito, vuelve a enmarcar a Cañizares en una dramaturgia que ya había experimentado todo lo posible y que a él, como autor, no le quedaba nada por innovar:

Hace lamentar que tan frondoso y natural ingenio malgastase sus fuerzas en imitaciones de escuelas y de estilos que ya habían caducado, y en las que, por muy buenas que fueran, nada superior quedaba por hacer ${ }^{73}$.

Hasta aquí, los juicios, valoraciones y enseñanzas de los propios dramaturgos. Ahora pasaremos de estudios específicos a otros más generales en los que Cañizares volverá a ser tratado con diferente suerte.

\subsection{Las primeras Historias de la Literatura}

Gil de Zárate en su Manual de Literatura (1844) reconoce el talento de nuestro autor para las comedias de figurón ${ }^{74}$; pero ya sopesa la influencia

\footnotetext{
${ }^{70}$ La crítica..., 2000, p. 27.

71 HARTZENBUSCH, 1845, pp. 372-402. Se puede comparar con el mismo trabajo que hace don Nicolás FERNÁNDEZ DE MORATÍN en su Disertación (pp. 60-61).

72 MESONERO RoMANOS, ed. 1859, p. XX.

${ }^{73}$ Idem, p. XXI.

74 Vol. II, 1874, p. 521.
} 
de la literatura francesa del siglo XVIII en Cañizares. Aunque éste siguió formalmente la dramaturgia del siglo XVII, quiso imitar a Moliére pero no tuvo éxito porque las obras del francés tampoco estaban arregladas al arte y el resultado fueron unas comedias de figurón muy recargadas ${ }^{75}$.

Fruto del interés por recopilar y ordenar el corpus de obras y autores españoles, Cayetano Alberto de la Barrera publica el Catálogo bibliográfico y biográfico del teatro antiguo español, desde sus orígenes hasta mediados del siglo XVIII (1860), donde aparecen los datos más completos sobre la vida y obra de Cañizares hasta el siglo XIX.

Más adelante, publica Álvarez Espino el Ensayo histórico-crítico del teatro español (1876) donde valora de forma muy positiva a Cañizares, situando, por ejemplo, la caracterización del personaje del dómine Lucas por encima de don Toribio de Cuadrillos, de Calderón; del lindo don Diego, de Moreto; de don Lucas del Cigarral, de Rojas y de don Claudio, de Zamora ${ }^{76}$ o señala varias comedias como ejemplo de buen estilo, seriedad en el pensamiento, arte en la disposición y en la trama, sin nombrar sus defectos ${ }^{77}$. En definitiva, como toda la crítica romántica, contempla a nuestro autor como el último que perteneció a la escuela del teatro antiguo español y así lo refleja de una manera grandilocuente y decimonónica: «los múltiples caminos que a ella [la ruina del arte escénico] condujeron y las diferentes heridas que ingenios infelices y despiadados abrieron en el pecho de Talía, para hacerla espirar en brazos del gracioso Cañizares» ${ }^{78}$.

Menéndez Pelayo en su tercer volumen de Historia de las ideas estéticas, trata con benevolencia a Cañizares y destaca que «en ellos mismos, y aun contra su voluntad, si bien se repara, empiezan a notarse como síntomas de algo nuevo, y una tendencia que no va hacia la comedia francesa, pero que en algunos puntos pudiera, sin grande esfuerzo, darse la mano con ella» ${ }^{79}$ y, como ejemplo, resalta sus comedias de figurón, y lo considera un «débil imitador» de los dramaturgos del siglo XVII ${ }^{80}$.

No hay que olvidar el interés que por nuestro teatro se tomaron algunos hispanistas extranjeros a raíz de los estudios de los Schlegel, y por esta razón, recurriremos a los escritos de dos de ellos. Para el profesor norteamericano Ticknor, las comedias de Cañizares son de género antiguo y fue el autor que más tiempo y mejor siguió el camino trazado por Lope y Calderón. Le acusa de coger fragmentos de edificios maravillosos para construir ruinas ${ }^{81}$. Según el prólogo que escribe a su Historia de la literatura española, Ticknor

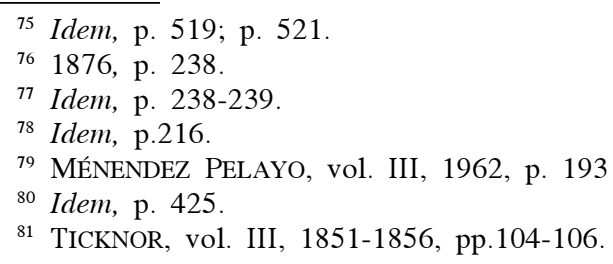


se nos descubre como un fiel seguidor de los Schlegel ${ }^{82}$ por lo que podemos deducir su valoración real de Cañizares: representa la decadencia del espíritu nacional, que ya empezó después de Carlos $\mathrm{V}$, según el historiador ${ }^{83}$.

Schack, el crítico alemán, lo considera «más que un poeta, un compositor de mosaicos» ${ }^{84}$ y esa habilidad para reunir materiales y componerlos, «indican la flexibilidad de su talento y su diligencia, y el dominio poco común que tenía en el manejo de los medios técnicos de la representación escénica; pero revelan a la par poca originalidad y escasa fuerza creadora» ${ }^{85}$. Vuelven a incidir en su capacidad para imitar y, sobre todo, su conocimiento de la puesta en escena: primera ocasión en la que se desciende al terreno práctico. En resumen, los críticos románticos y extranjeros son menos indulgentes con Cañizares porque no les asistía el prurito de defender el teatro español de las influencias foráneas que, en definitiva, era defender la idiosincrasia del país.

En la consideración general de Cañizares y de Zamora por los estudiosos del siglo XIX, «seguirán siendo citados en los repasos por el teatro nacional, aunque pronto son reemplazados por los adalides del nuevo gusto: Moratín, Cadalso, López de Ayala (...)» ${ }^{86}$.

\section{EL SIGLO XX}

\subsection{Historias de la Literatura}

Julio Cejador es el primero que inaugura el siglo con su obra Historia de la Lengua y Literatura española (1916) y en ella comenta los aspectos ya conocidos de nuestro dramaturgo: su «especial acierto en las comedias de figurón» ${ }^{87}$ y las imitaciones que realizó de Racine y Metastasio, con un resultado poco positivo ${ }^{88}$. Prácticamente, se repiten las mismas ideas en los escritos de Fitzmaurice-Kelly ${ }^{89}$, Díez de Escovar ${ }^{90}$ y Hurtado ${ }^{91}$. Hay que esperar a Ángel Valbuena y a su Historia de la literatura española, para encontrar una crítica más sólida, aunque no totalmente distinta de lo que ya conocemos: afirma que Cañizares es el último dramaturgo que imitó la forma nacional, le encuentra similitudes con Lope y Calderón, destacando es-

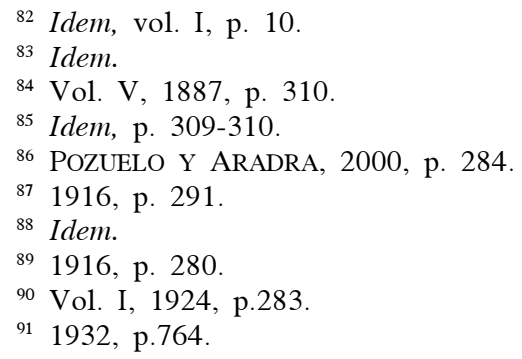


pecialmente la estructuración de la obra $^{92} \mathrm{y}$, en cuanto a las adaptaciones extranjeras, nuestro autor tiene presente los modelos clásicos griegos ${ }^{93}$.

Juan Luis Alborg publica su conocida Historia de la literatura española en 1972. Paradójicamente, cuando se refiere a Zamora y Cañizares, lo hace en el capítulo VII «Teatro neoclásico», en el apartado «La dramaturgia neoclásica» y bajo el epígrafe «Los últimos dramaturgos del Barroco», donde viene a decir que los autores de ese momento cultivan formas exhaustas del Barroco, excepto Zamora y Cañizares. Señala las preferencias de éstos para adaptar comedias del siglo XVII con bastante libertad ${ }^{94}$. Quizás estas incongruencias puedan venir dadas por su adscripción a la teoría sobre la literatura española de Menéndez Pidal y por la misma tradición crítica sobre estos autores, donde resuenan los ecos de los Schlegel:

Menéndez Pidal, que ha defendido, como dijimos, el concepto tradicional aplicado a la literatura, sostiene consecuentemente la existencia de caracteres dominantes [...]. Menéndez Pidal considera un hecho de experiencia común «la enorme coacción que sobre el individuo ejercen las ideas y sentimientos de sus coetáneos [...] y el acto más independiente de creación individual participa de los caracteres dominantes en lo común de cada nación ${ }^{95}$

En la década de los ochenta aparecerán una serie de Historias de la Literatura española que empujarán con nuevos aires la crítica sobre los autores de los primeros años del siglo XVIII; quizás, también, porque ha cambiado, en cierta medida, la concepción de la autoría de las «Historias»: no es obra de un único autor que domina todo el amplio y vasto campo de la literatura, sino de varios autores, dirigidos por un coordinador, expertos en el tema una parcela concreta; por ejemplo, La Historia de la Literatura española, coordinada por Díez Borque, el capítulo «El teatro en el siglo XVIII» está redactado por R. Andioc y éste propone nuevas visiones de la obra de Cañizares, de acuerdo a lo ya expresado en su libro Teatro y sociedad en el Madrid del siglo XVIII ${ }^{96}$. Sirva como ejemplo este fragmento:

Las razones de un cambio de óptica tan radical no se pueden explicar sino por una paulatina evolución de la comedia a principios del siglo XVIII: conviene preguntarse, en efecto, gracias a los continuadores de Calderón y al público para quien escribían, si los valores expresados por el teatro del gran dramaturgo no se percibían a través del prisma de una sicología social ya bastante diferente de la del siglo anterior. En efecto, se ha advertido durante los primeros decenios del xviii en las obras teatrales de Zamora, Cañizares y otros contemporáneos, una debilitación no tanto de los principios como de las manifestaciones del sentimiento caballeresco ${ }^{97}$.

\footnotetext{
92 Vol. III, 1950, p. 421-422.

93 Idem, p. 448.

94 Vol. III, 1972, p. 608-610.

95 Idem, vol. I, p. 15.

96 1987, 20 a ed. corr. y aument.

97 ANDIOC, vol. III, 1980, pp. 224-225.
} 
La Historia de la Literatura, dirigida por García de la Concha y coordinada por Guillermo Carnero, sigue este mismo método de trabajo y, gracias a él, ya encontramos en la historia de la literatura en el capítulo «El Teatro en el siglo XVIII (1)», Cañizares aparece en los distintos géneros de comedias: de santos, militares, de magia, etc. ${ }^{98}$; también, se expone la importancia del teatro italiano, la presencia de las zarzuelas en la Corte, etc. y donde son nombradas por primera vez las zarzuelas compuestas por Cañizares para Palacio ${ }^{99}$.

También se publican Historias de la Literatura con un esquema sencillo y, a la vez, completo, buscando lo esencial de cada autor, como la elaborada por Felipe Pedraza y Milagros Rodríguez. Comentan brevemente la biografía del escritor y sus obras principales sin llegar a hacer un estudio de más calado como el anterior, al que hemos hecho referencia, y de Cañizares no aportan nada nuevo ${ }^{100}$.

Desde los años 80, los investigadores han contado para el estudio de la literatura del siglo XVIII y del teatro son las importantes publicaciones de la Bibliografía de autores del siglo XVIII de Aguilar Piñal (1981-2001), el Catálogo de autores teatrales del siglo XVIII (1993) y los sucesivos artículos y el libro de Mercedes Agulló sobre la colección de teatro de la Biblioteca Histórica Municipal de Madrid (1969-2005). En estas obras, el estudioso puede acceder a los manuscritos e impresos de las obras de Cañizares conservadas en las principales bibliotecas españolas, europeas y americanas.

\subsubsection{Historias del Teatro español}

El primer estudioso que se decidió a escribir una Historia del Teatro español (desde sus orígenes hasta 1900) fue el profesor Ruiz Ramón y de Cañizares, opinaba, de acuerdo con la tradición anterior:

su labor consistía, casi exclusivamente, en refundir, sin capacidad para recrear, el haber dramático heredado. Poseían [Zamora y Cañizares] tan sólo un mecanismo de construcción teatral, una habilidad técnica y unas formas teatrales al servicio de una temática estereotipada y desustanciada. Podían repetir combinando, pero no crear nada nuevo ${ }^{101}$.

Hasta finales de la década de los ochenta, no aparecerá otra Historia del teatro en España, dirigida por José M. ${ }^{a}$ Díez Borque y que encarga el tomo

98 Vol, VI, 1995, pp.294-411. Está compuesto por cuatro artículos: René ANDIOC, «Organización y características de la vida teatral», pp. 295-312; Joaquín ÁLVAREZ BARRIENTOS y Miereille COULON, «El teatro clásico español en el siglo XVIII», pp. 312-347; Joaquín ÁlVAREZ BARRIENTOS, «Formas populares y de consumo», pp. 347-372; Teresa CHAVES MONTOYA y Fernando R. DE LA FLOR, «El teatro musical», pp. 372-399.

99 Idem, pp. 372-382.

100 Vol. V, 1981, pp. 279-281.

101 1983, p. 285. 
correspondiente al siglo XVIII a Emilio Palacios. Éste se ocupa de Cañizares, haciendo resaltar sus comedias heroicas, de santos, de magia y de figurón. Cita las zarzuelas pero no señala si fueron estrenos palaciegos o no ${ }^{102}$.

Cronológicamente, la siguiente obra de la que nos ocuparemos es la Historia del teatro español del siglo XVII, escrita íntegramente por el profesor Ignacio Arellano en la que se limita a mostrar el teatro hasta finales del Seiscientos y en el capítulo dedicado a los dramaturgos menores del ciclo de Calderón, introduce a Cañizares, considerándolo como un «barroquista del XVIII» ${ }^{103}$, sin más valoración, comentario o estudio.

Para terminar este breve recorrido, sólo nos queda comentar la última Historia del teatro español, dirigida por Javier Huerta Calvo en la que, según su coordinador, «se trata de ofrecer, de modo sistemático, el conjunto de perspectivas que convergen en la mirada del texto teatral, tanto en la dimensión literaria como espectacular: arte escénico, teoría teatral, autores y obras, transmisión y recepción» ${ }^{104}$. La producción de Cañizares y su análisis aparece dispersa a lo largo de los distintos capítulos que tratan del siglo XVIII: Palacios estudia de forma general el teatro tardobarroco, Coulon profundiza en la recepción del teatro del siglo XVIII, Jose Máximo Leza aborda la cuestión de las zarzuelas y del teatro musical, etc. ${ }^{105}$ y la conclusión llega en palabras de Fernando Doménech: Cañizares «necesita nuevos trabajos que valoren su contribución al teatro del momento» ${ }^{106}$.

\subsection{Artículos}

El primero que inaugura la serie en el tiempo (1924) es de Manuel Machado y el contenido del artículo versa sobre una cuestión que antes nadie había estudiado: la autocensura del propio Cañizares sobre una refundición de La Niña de la Plata de Lope ${ }^{107}$ y hasta el año 2006 no encontraremos el artículo de Susan Paun que también trata de esta cuestión en relación con las comedias de magia ${ }^{108}$.

Siguiendo la estela de un Cañizares refundidor o imitador, los críticos han dedicado la mayoría de sus esfuerzos a estudiar en los artículos este tipo de obras, pero más que para valorar y sopesar la figura de Cañizares, la han realizado cara al autor «refundido» es decir, Lope, Diamante u otros dramaturgos del Siglo de Oro; así tenemos los estudios sobre comedias

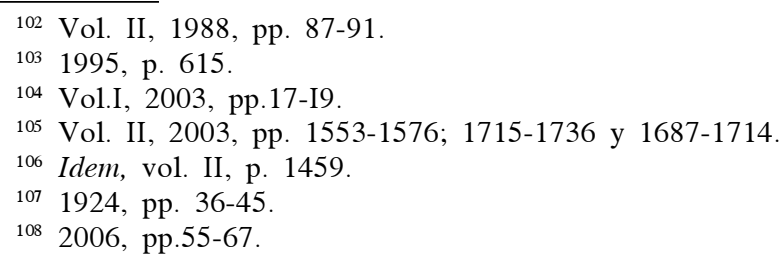


novelescas El Falso Nuncio de Portugal ${ }^{109}$, El Picarillo en España ${ }^{110}$, El Pleito de Hernán Cortés ${ }^{111}$; de argumento histórico Lo que va de cetro a cetro y Crueldad de Inglaterra ${ }^{112}$; comedias de santos: La viva Imagen de Cristo ${ }^{113}$, La más amada de Cristo, Santa Gertrudis la Magna ${ }^{114}$; El asombro de Jerez, Juana la Rabicorta ${ }^{115}$, A cual mejor, confesada y confesor ${ }^{116}$ o de figurón: El dómine Lucas ${ }^{117}$. La mayoría de los autores de los referidos artículos no aportan nada nuevo a la crítica tradicional sobre nuestro autor, quizás, con la excepción de Rull que sitúa su estudio sobre El Picarillo de España en un contexto diferente:

No es, por consiguiente, el teatro del post-barroco una mera prolongación del anterior, sino un intento, formalmente no conseguido, por describir una nueva visión de la realidad con unos rígidos medios convencionales [...]. Si la estética de la obra es proyección del Barroco, el alcance de la visión del mundo mira hacia delante, con balbuceos y timideces, sin duda, pero con cierto aire de novedad. Creemos, en suma, que debería prestarse una mayor atención a esta época, cuyo análisis pormenorizado daría resultados globales que bastarían para imponer en nuevo concepto más positivo del momento literario ${ }^{118}$.

Este testigo lo recogerá años más tarde, el profesor Vitse que propondrá el concepto de «modernización» para el teatro de Cañizares ${ }^{119}$. Según el citado investigador, Cañizares maneja con soltura las técnicas teatrales calderonianas, pero «un manejo informado por el espíritu que fue característico de la primera generación del siglo precedente, es decir, esa generación acaudillada por Lope y por Tirso» ${ }^{120}$. Los literatos inmersos en un parecido tiempo histórico obedecen a un movimiento de modernización que les lleva a una puesta al día del ideario antiguo ${ }^{121}$.

Esta matización del crítico francés la analiza y critica agudamente Pérez Magallón ${ }^{122}$, situando el teatro de Cañizares en su época, en el ambiente teatral de su tiempo, desterrando los clichés e ideas preconcebidas, e integrándolo en la corriente de «creación de un nuevo teatro en los años de la transición del Barroco a la Ilustración» ${ }^{123}$. Esta hipótesis, unida a un empe-

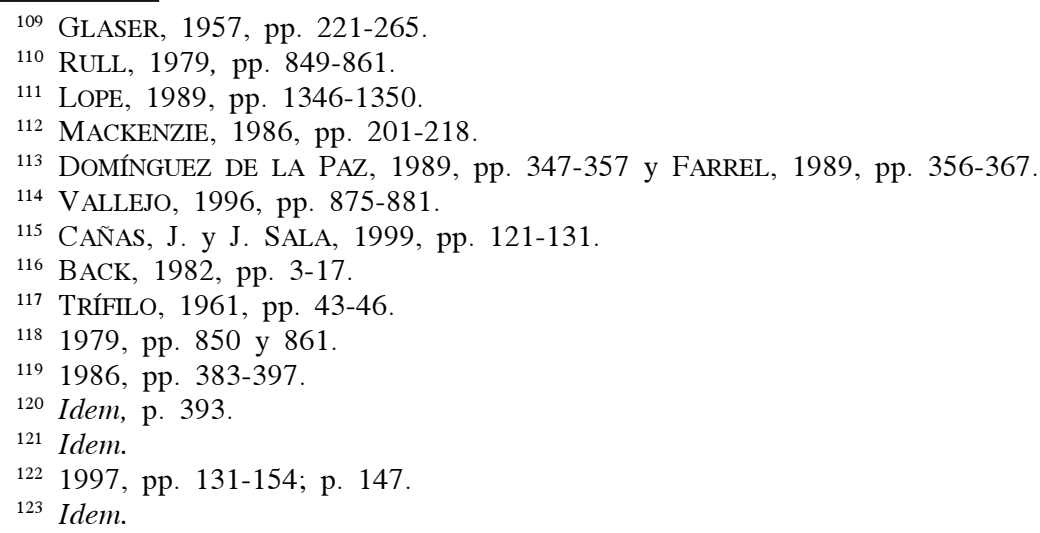


ño por esclarecer la cultura a lo largo de esos años finales del siglo XVII y principios del siglo XVIII, sigue defendiendo y profundizando en otros artículos y en su libro monográfico sobre los novatores ${ }^{124}$.

\subsection{Monografías}

También hay libros que tratan directamente sobre nuestro autor, concretamente, $L$ 'art dramatique en Espagne dans la premiére moitié du XVIII siécle, de $\mathrm{P}$. Merimée ${ }^{125}$, la tesis universitaria de José Onrubia de Mendoza, El teatro de José de Cañizares ${ }^{126}$; José de Cañizares, dramaturgo olvidado del siglo XVIII, de Alva V. Ebersole (1975) y José de Cañizares, traditionalist and innovator, de Kim L. Johns (1981).

La obra del hispanista francés, quizás sea la más completa de las que hemos citado, entre otras razones, porque acude a fuentes documentales, elabora el listado de las obras con la fecha de su estreno e indica dónde se encuentran los manuscritos ${ }^{127}$. Hace una valoración crítica sobre Cañizares en el segundo capítulo de la Primera Parte "La Fin de la Comedia, ou La Mort d'un monde» ${ }^{128}$ en la que nos ofrece los problemas de atribución, una posible división temática de las comedias y, sobre todo, concluye con una visión más moderna de Cañizares:

Cañizares, supplée à son manque de personnalité par son talent d'utilisateur et son don théâtral. Sa carrière désormais reconstituée, son oeuvre en grande partie datée le montrent sensible à son temps ${ }^{129}$.

La tesis universitaria de Onrubia de Mendoza es el primer intento serio realizado en España de estudiar gran parte de la obra y de interpretarla. El autor se decanta por establecer tres épocas en la obra de Cañizares y así va dando cuenta de sus innovaciones:

En un segundo periodo, que situaríamos entre 1705 y 1715, Cañizares va separándose del teatro del siglo XVII y creando una serie de elementos de origen claramente «dieciochesco», como son una sensibilidad de tipo musical, un fermento revolucionario casi inconsciente [...], una técnica teatral que sin aceptar de una manera expresa las reglas del clasicismo se acerca a ellas en bastantes ocasiones. La tercera etapa [...] tiene una duración aproximada de veinte años y se mezclan en ella los elementos heredados y los nuevos, predominando unos u otros según el género y las circunstancias, dentro de un teatro que no creemos que en ningún momento pueda confundirse con el de nuestro siglo XVII ${ }^{130}$.

\footnotetext{
124 2002. Para el resto de los artículos, véase la bibliografía.

125 Toulouse, 1955 (1 édition dactylographiée), 1983 (12ºdition imprimée).

1261965 (extracto de la tesis).

127 1983, pp. 480-488.

128 Idem, pp. $81-142$

129 Idem, p. 469.

130 1965, p. 19.
} 
Llega a concretarlas aún más señalando que el ambiente musical, la evolución del «gracioso» y del figurón, el nuevo concepto del honor, el tipo de concentración métrica y estructural dan «unidos todos ellos, la comedia de la primera mitad del nuestro siglo XVIII» ${ }^{131}$. Estas afirmaciones, desgraciadamente, no podemos leerlas en su forma desarrollada ya que el texto que poseemos es sólo el extracto de una tesis. Sería muy útil ver publicado en su totalidad este trabajo.

Los estudios de los dos investigadores anglófonos continúan ofreciendo este aspecto distinto de Cañizares. Ebersole opina:

Y yo digo que debemos examinar la obra de Cañizares, en relación a su momento histórico, como dramaturgo que sabía satisfacer el gusto popular al mismo tiempo que no se olvidaba de su deber de «enseñar deleitando y deleitar enseñando», siguiendo las reglas preestablecidas de la comedia española y no de la francesa, adaptándose siempre a la nueva moda, especialmente en lo tocante al género lírico, y aprovechándose de las posibilidades de escenificación que permitían los últimos adelantos mecánicos introducidos en el teatro de dicha época ${ }^{132}$.

Sin embargo, no hace ninguna alusión al trabajo de Merimée —como se lamenta éste en la reedición de $L$ 'art dramatique ${ }^{133} \ldots$ - ni se hace eco de otros trabajos, ya que sólo se imita a dar la lista de comedias y a resumir los contenidos de la mayoría de ellas.

Para Kim L. Johns, «Cañizares is both a traditionalist who bases his dramatic method upon the techniques of the seventeeth-century Spanish theater, and an innovator who recognizes new potential in the eighteenthcentury theatre» ${ }^{134}$. Parece que intenta tomar una nueva postura, aunque en su libro no desciende a señalar cuál es ese «nuevo potencial del teatro del siglo XVIII» que advierte en Cañizares.

\subsection{Ediciones}

Desde Moratín, los críticos han repetido hasta la saciedad el número de obras aproximadas de Cañizares: unas ochenta ${ }^{135}$. Un índice evidente del interés que suscitan las comedias de Cañizares en los estudiosos es el número de ediciones críticas y qué obras han sido estudiadas en ellas y si han cubierto gran parte de la producción del autor. Veamos por orden cronológico ${ }^{136}$ :

131 Idem.

132 EBERSOLE, 1975, pp. 13-14.

133 1983, p. 120, n.14.

134 JOHNS, 1981, p. 121.

135 FERNÁNDEZ DE MORATÍn, Discurso preliminar., ed. 1860, p. 312.

$136 \mathrm{Me}$ ceñiré a las ediciones críticas filológicas. En musicología se ha suscitado un gran interés por las zarzuelas del s. XVIII y algunos de los libretos publicados pertenecen a Cañizares: 
- Mesonero Romanos, Ramón, Dramáticos posteriores a Lope de Vega. Colección escogida y ordenada por don t. II, BAE, vol. 44, Madrid, Rivadeneyra, 1859 publica: El Dómine Lucas; El Picarillo de España; Abogar por su defensor y Barón del Pinel; El honor da entendimiento y el bobo hace más; La más ilustre fregona; Por acrisolar su honor, competidor hijo y padre; Yo me entiendo y Dios me entiende. Hasta finales del siglo XIX no fueron accesibles estas obras en una edición moderna. Ésta, a la que nos referimos, sólo cubre el hueco de poder leerlas sin acudir al teatro. No hay más interés filológico en ellas que comprobar cuáles eran consideradas las mejores de nuestro autor.

- El niño inocente de Lope de Vega; y La viva Imagen de Cristo de José de Cañizares; transcripción y estudio histórico-crítico de Manuel Romero de Castilla; prólogo del Marqués de Lozoya, Madrid, [s.n.], 1943. Como se refleja en el título, la exposición que hace Manuel Romero es de tipo histórico, examina las fuentes ${ }^{137}$ y con respecto a los textos, sólo los transcribe, sin aclaración ni notas críticas o filológicas. No defrauda el autor porque lo advierte:

Las dos comedias, y principalmente la de Lope, no son adaptadas a la representación teatral, por la sinceridad en el contenido y viva interpretación de documentos originales, como es fácil deducir por la lectura de las obras, en las que el rigor de algunas escenas sería insoportable para los espectadores. Se pueden considerar las dos obras transcriptas un documento histórico adaptado al estudio y conocimiento del importante suceso, y una exposición más amena y menos monótona, por la elevación de pensamientos e influencia poética ${ }^{138}$.

- Angélica y Medoro ed. Julius A. Molinaro y Warren T. Mc. Cready, Tormo, Quaderni Ibero-Americani, Collana di testi e studi, n. ${ }^{\circ} 3$, 1958. Esta edición de un manuscrito inédito de la Biblioteca Nacional cuenta con un

- Salir el amor del Mundo, Zarzuela en dos jornadas de S. Durón y Cañizares, transcripción y estudio de Antonio Martín Moreno, Málaga, Sociedad Española de Musicología, 1979;

- Amor aumenta el valor. Melodrama. Primer acto. Música de José de Nebra; texto de José de Cañizares, estudio y transcripción, María Salud Álvarez Martínez, Institución «Fernando el Católico», Zaragoza, 1996;

- Vendado es amor no ciego. [Música impresa de José de Nebra, libreto de José de Cañizares] estudio y transcripción, María Salud Álvarez Martínez, Zaragoza, Institución Fernando el Católico, 1999;

- Literes, A. Acis y Galatea. Zarzuela en dos jornadas, ed. de L.A. González Marín, Madrid, Instituto Complutense de Ciencias Musicales (ICCMU), 2002;

- El imposible mayor en amor, le vence amor: zarzuela en dos jornadas; música de Sebastián Durón, libreto de Francisco Candamo y José de Cañizares; edición crítica, Antonio Martín Moreno, Madrid, Instituto Complutense de Ciencias Musicales (ICCMU), 2005

Las ediciones de las zarzuelas de Cañizares son objeto de un trabajo que publicaré en breve.

137 1943, p. 9-21.

${ }^{138}$ Idem, p. 21. 
brevísimo estudio previo a la zarzuela, que abarca siete páginas ${ }^{139}$ en los que se dan escasas noticias del autor, de la representación y del tema. Respecto al texto, sólo varía lo correspondiente a la acentuación o puntuación y no hay notas de carácter filológico o crítico. Es la primera zarzuela palaciega accesible a una edición moderna.

- Entremés de Bartolo Tarasca, edizione, introduzione e note a cura di Antonietta Calderone, Messina, Peloritana, 1979. Es la única edición crítica filológica de una pieza breve de José de Cañizares. En la introducción la autora pone de manifiesto las posibilidades de investigación que ofrece este periodo del teatro español. La profesora Calderone hace una valoración crítica de las supresiones, añadidos y variantes que ofrece el único manuscrito conservado del entremés; además, presenta la fiesta del Corpus y la tarasca para lectores ajenos a la tradición teatral española. Después del texto aporta dos apéndices: uno sobre la compañía que lo interpretó y otro con documentos del Archivo de la Villa de Madrid referentes a la elaboración de la tarasca de 1723.

- El anillo de Giges, ed. Joaquín Álvarez Barrientos, Madrid, CSIC (Anejos de la revista «Segismundo», n. ${ }^{\circ}$ 9), 1983. Nos encontramos ante la edición crítica de una de las comedias de magia con más éxito. El lector encontrará un estudio introductorio pormenorizado sobre el autor, las comedias de magia, su dramaturgia y, lo que nos parece más significativo, valora la obra de Cañizares en su tiempo.

- El pastelero de Madrigal, rey don Sebastián fingido, edición, introducción y notas de Rafael Lozano Miralles, Parma, Zara (Biblioteca teatrale e musicale, n. ${ }^{\text {o } 3), ~ 1995 . ~ E s ~ u n a ~ e d i c i o ́ n ~ c r i ́ t i c a ~ q u e ~ c o t e j a ~ l o s ~ n u m e r o s o s ~}$ manuscritos e impresos de esta obra de tema novelesco; pero no ofrece un estudio completo de la obra.

- Don Juan de Espina en su patria; Don Juan de Espina en Milán, edición, introducción y notas de Susan Paun de García, Madrid, Consejería de Educación y Cultura, Secretaría General Técnica, Clásicos madrileños, n. ${ }^{\circ}$ 17, 1997. Considera en el estudio la importancia de las comedias de magia $\mathrm{y}$, concretamente, en la producción del autor. Hace una breve reseña de la vida de Cañizares, que no aporta nada nuevo y basa las dos ediciones críticas en unos impresos de 1745, no en los manuscritos que se conservan; aunque la autora promete en breve su publicación.

- La ilustre fregona, introduzione, testo critico e note di Marco Presotto, Rimini, Panozzo (Testi inediti e rari, n. ${ }^{\circ}$ 6), 2001. Nos encontramos ante una buena edición textual, donde se explican con detalle los distintos testimonios. En el estudio introductorio, sitúa a Cañizares en la transición del siglo XVII al XVIII. Es una edición seria desde el punto de vista filológico y

\footnotetext{
139 1958, pp. 7-13.
} 
crítico sobre Cañizares; aunque en el estudio previo, pone más énfasis en la obra de Lope, en la que se basa nuestro autor.

Cañizares es un dramaturgo popular y prolífico. Está considerado como un adaptador de obras antiguas sin mucha fortuna y, unánimemente, se aprecia su especial genio para las comedias de figurón. Algunos autores plantean que si hubiera nacido en otro siglo, hubiera escrito mucho mejor; Forner opina que escribió «monstruos agradables»; para Luzán, fue el mejor «genio cómico». Los detractores acuden a las reglas y a su poca creatividad en la imitación de las comedias del Siglo de Oro y de las francesas e italianas ${ }^{140}$. La mayoría de los críticos no hacen referencia a su producción palaciega.

En la crítica romántica, Lista, Hartzenbusch y Mesonero Romanos, luchan por desterrar el tópico de la literatura española como imitación de la francesa y de que no existía un genuino espíritu español. Quieren destacar que hubo en el siglo XVIII una verdadera plasmación del carácter español nacional y ponen a Cañizares como ejemplo. En estos dos siglos, Cañizares ha sido estudiado siempre con ideas preconcebidas desde las reglas dieciochescas o el nacionalismo romántico, por lo que nunca ha salido a relucir su verdadero arte, con sus defectos y aciertos.

En el siglo XX vamos a encontrar una gran variedad de planteamientos ya repetidos desde los siglos anteriores o con una visión nueva. Las historias de la literatura continúan considerando a Cañizares como epígono del teatro del Siglo de Oro, hasta que R. Andioc en los años 80, basándose en las fuentes documentales, comienza a introducir cuestiones que provocan un cambio en la percepción de nuestro dramaturgo y de su época; después, Díez Borque, Arellano o Huerta también intervienen a favor de Cañizares porque influye la nueva visión del teatro como espectáculo y los estudios de Pérez Magallón avanzan en el planteamiento general de su dramaturgia.

Con la proliferación de las ediciones críticas, quizás sean éstas las que mejor nos enseñen la relevancia o no de la figura de Cañizares para la crítica actual. Sólo encontramos las siguientes ediciones filológicas — de las más de ochenta obras que componen el repertorio de Cañizares-: Entremés de Bartolo Tarasca (1979); El anillo de Giges (1983); El pastelero de Madrigal, rey don Sebastián fingido (1995); Don Juan de Espina en su patria; Don Juan de Espina en Milán (1997) y La ilustre fregona (2001): una pieza menor, tres comedias de magia y dos novelescas, amén de la edición histórica-crítica que nos ofrecen los dos textos juntos pero sin ninguna precisión más.

Sólo hay que observar las fechas de edición para comprobar que el interés de los filólogos es de carácter puntual y no sólo se han acercado a una mínima parte de sus obras, sino que no se han acercado todavía a las más importantes y significativas como El dómine Lucas (que ya M. Vitse llamaba la atención de la necesidad de su edición crítica), La viva Imagen

140 Pérez Magallón, 1997, p. 132. 
de Cristo que tantos artículos ha suscitado, El músico por amor o El montañés en la Corte, las famosas comedias de magia Marta la Romarantina (con todas sus partes) o Juana la Rabicorta, las aplaudidas comedias de santos Santa Gertrudis la Magna, A cada cual mejor confesada y confesor, etc.; gracias a los artículos y a las monografías, había ya un material con el que podría haberse realizado estudios igualmente interesantes y esclarecedores del teatro de Cañizares.

Al contemplar este panorama crítico, nos lleva a reivindicar que Cañizares sea estudiado en y desde su época. «Basta, pues, de considerar el teatro de Bances, Zamora y Cañizares como decadente» ${ }^{141}$ : a través de los documentos y de la concepción espectacular, resulta más idóneo tratar la realidad teatral de Cañizares, sin necesidad de introducirla en estrechos cánones o reglas, «dejando que hablen» los textos y los datos de la época. La edición crítica de sus obras, la investigación en los archivos y bibliotecas ayudarían a este fin: descubrir la importancia que tuvo Cañizares en el tiempo histórico de transición que vivió y en el teatro.

\section{BIBLIOGRAFÍA CRÍTICA}

\section{Manuscritos e Impresos}

ANTI-LOA para la cerradura del teatro de Sevilla su autor D.J.P.F.F., Biblioteca Capitular de Sevilla, Varios, 60-1-1, 34.

CAMARGO, Ignacio, Discurso theologico sobre los teatros y comedias de este siglo, Salamanca, 1689.

FeIJOO, Fr. Benito Jerónimo, Cartas eruditas y curiosas (...) escritas por vol. I, Madrid, En la Imprenta Real de la Gazeta: A costa de la Real Compañia de Impresores, y Libreros, 1777 .

FORNER, Juan Pablo, «Introducción o Loa para la apertura del teatro en Sevilla», Obras de Forner, vol. V, ¿1796?, pp. 26-55. BN, Ms 9586.

MERCURIO histórico y político, 3 vols., Madrid, Imp. de Manuel Fernández, 1738.

MERCURIO histórico y político, 3 vols., Madrid, Imp. Diego Manuel de Peralta, 1739.

PITILLAS, Jorge, «Sátira contra los malos escritores de este siglo», Diario de los Literatos de España, vol. VII, 1742.

\section{Ediciones críticas de José de Cañizares}

Amor aumenta el valor. Melodrama. Primer acto. Música de José de Nebra texto de José de Cañizares; estudio y transcripción, Maria Salud Álvarez Martínez, Institución «Fernando el Católico», Zaragoza, 1996.

Angélica y Medoro ed. Julius A. Molinaro y Warren T. Mc. Cready, Tormo, Quaderni Ibero-Americani (Collana di testi e studi, n. ${ }^{\circ}$ 3), 1958.

El anillo de Giges, ed. Joaquín Álvarez Barrientos, Madrid, CSIC (Anejos de la revista «Segismundo», n. ${ }^{\circ}$ 9), 1983.

Entremés de Bartolo Tarasca, edizione, introduzione e note a cura di Antonia Calderone, Messina, Peloritana, 1979.

La ilustre fregona, introduzione, testo critico e note di Marco Presotto, Rimini, Panozzo, (Testi inediti e rari, n. ${ }^{\circ}$ 6), 2001.

${ }^{141}$ Pérez Magallón, 1997, p. 148. 
El imposible mayor en amor, le vence amor: zarzuela en dos jornadas; música de Sebastián Durón, libreto de Francisco Candamo y José de Cañizares; edición crítica, Antonio Martín Moreno, Madrid, Instituto Complutense de Ciencias Musicales (ICCMU), 2005.

Don Juan de Espina en su patria. Don Juan de Espina en Milán, edición, introducción y notas de Susan Paun de García, Madrid, Consejería de Educación y Cultura, Secretaría General Técnica (Clásicos madrileños, n. ${ }^{\circ}$ 17), 1997.

El niño inocente de Lope de Vega y La viva imagen de Cristo, transcripción y estudio histórico-crítico de Manuel Romero de Castilla, prólogo del Marqués de Lozoya, Madrid [s.n.], 1943

El pastelero de Madrigal, rey don Sebastián fingido, edición, introducción y notas de Rafael Lozano Miralles, Parma, Zara (Biblioteca teatrale e musicale, n. ${ }^{\circ}$ 3), 1995.

Salir el amor del Mundo. Zarzuela en dos jornadas de S. Durón y Cañizares, Transcripción y estudio de Antonio Martín Moreno, Málaga, Sociedad Española de Musicología, 1979.

- y Antonio de LITERES, Acis y Galatea. Zarzuela en dos jornadas, ed. de L.A. González Marín, Madrid, Instituto Complutense de Ciencias Musicales, 2002.

- y José de NEBRA, Obra selecta [Música impresa] Vendado es amor, no es ciego. Estudio y transcripción María Salud Álvarez Martínez, Zaragoza, Institución Fernando el Católico, 1999.

\section{Obras consultadas}

ABELlán, José Luis, Historia crítica del pensamiento español. Del Barroco a la Ilustración, vol. III, Madrid, Espasa-Calpe, 1988.

AGUILAR PIÑAL, Francisco, Bibliografía de autores del siglo XVIII, Madrid, CSIC, 10 vols., 1981-2001.

Agulló Y COBo, Mercedes, «La Colección de Teatro de la Biblioteca Municipal de Madrid», Revista de Literatura, fasc. 71-72 (1969), pp. 169-213.

-, Idem, fasc. 73-74 (1970), pp. 233-274.

-, Idem, fasc., 75-76 (1976), pp. 189-252.

—, Revista de Bibliotecas, Archivos y Museos, n. ${ }^{\circ} 1$ y 2 (1977), pp. 179-231.

—, Idem, n. ${ }^{\circ} 3$ y 4 (1978), pp. 125-187.

—, Idem, n. ${ }^{\circ} 5$ (1979), pp. 193-218.

—, Idem, n. ${ }^{\circ} 6$ (1980a), pp. 131-190

—, Idem, n. ${ }^{\circ} 7$ y 8 (1980b), pp. 223-302.

—, Idem, n. ${ }^{\circ} 9$ y 10 (1981), pp. 103-183.

—, Idem, n. ${ }^{\circ} 11$ y 12 (1982), pp. 259-351.

- La colección de teatro de la Biblioteca Municipal de Madrid, Madrid, Biblioteca Histórica Municipal, 1995.

AlBORG, Juan Luis, Historia de la literatura española, Madrid, Gredos, vol. III, 1993, $11^{\mathrm{a}}$ ed. $1972,7^{\mathrm{a}}$ reimpr.

Álvarez ESPINO, Romualdo, Ensayo histórico-crítico del teatro español, Cádiz, Tip. La Mercantil, 1876

Álvarez DE BAENA, José Antonio, Hijos ilustres de Madrid, 4 vols., Madrid, Oficina de D. Benito Caro, 1790, [ed. facs. Madrid, Atlas, 1973].

ÁllVAREZ BARRIENTOS, J., «Formas populares y de consumo», Historia de la Literatura Española. Siglo XVIII (1), vol. 6, Víctor García de la Concha (dir.), Guillermo Carnero (coord.), Madrid, Espasa Calpe, pp. 347-372.

- y Mireille COULLON, «El teatro clásico español en el siglo XVIII», Historia de la Literatura Española. Siglo XVIII (1), vol. 6, Víctor García de la Concha (dir.), Guillermo Carnero (coord.), Madrid, Espasa Calpe, pp. 312-347, 1995.

ANDIOC, René, Teatro y sociedad en el Madrid del siglo XVIII, Madrid, Castalia, 1976; 1987, $2^{\text {a }}$ ed. corr. y aum.

—, «El teatro en el siglo XVIII», Historia de la literatura española. Siglo XVIII y siglo XIX, dirigida por José Ma Díez Borque, vol.III, Madrid, Taurus, 1988, pp. 199-290. 
—, «Organización y características de la vida teatral», Historia de la Literatura Española. Siglo XVIII (1), Víctor García de la Concha (dir.), Guillermo Carnero (coord.), Madrid, Espasa Calpe, 1995, pp. 295-312.

ARELlano, Ignacio, Historia del teatro español del siglo XVII, Madrid, Cátedra, 1995.

ARENAS CRUZ, M. Elena, Pedro Estala, vida y obra. Una aportación a la teoría literaria del siglo XVIII español, Madrid, CSIC, 2003.

BANCES CANDAMO, Francisco, Teatro de los theatros de los passados y presentes siglos, ed. Duncan W. Moir, London, Tamesis, 1970.

BARRERA, Cayetano Alberto de la, Catálogo bibliográfico y biográfico del Teatro Antiguo desde sus orígenes hasta mediados del siglo XVIII, London Tamesis Books Limited, (Támesis, Serie D: Reproducción en facs.), 1968.

BuCK, Donald C. «Popular theology, miracles and stagecraft in the Comedia de Santo Cañizares' A cual mejor, confesada y confesor...», Dieciocho, n. ${ }^{\circ}$ 1, vol. V (1982), pp. 3-17, 1981.

CALDERONE, Antonietta, «José de Cañizares, entre santas y magas», La comedia de magia y de santos, Madrid, Júcar, 1992, pp. 351-362.

CAÑAS, J. y J. SALA, «Humor y drama en «El asombro de Jerez, Juana, la Rabicorta» de José de Cañizares» Risas y sonrisas en el teatro de los siglos XVIII y XIX, editor Joseph Maria Sal Valldaura, Lleida, Editions Universitat de Lleida, 1999, pp.121-131.

CARMENA y MiLlán, Luis, Crónica de la ópera italiana en Madrid desde el año 1738 hasta nuestros días con un prólogo histórico de D. Francisco Asenjo Barbieri, introd. Emilio Casares Rodicio, Madrid, Instituto Complutense de Ciencias Musicales, 2002, ed. facs.

COTARELO Y MORI, Emilio, Orígenes y establecimiento de la ópera en España hasta 1800, Madrid, Tip. de la Revista de Archivos, 1917.

—, Historia de la zarzuela, Madrid, Tip. de la Revista de Archivos, 1934.

LA CRÍTICA ante el teatro barroco español:(siglos XVII-XIX), estudio introductorio, selección y edición de M. ${ }^{a}$ José Rodríguez Sánchez de León, Salamanca, Almar, 2000.

CEJADOR Y FRAUCA, Julio, Historia de la lengua y literatura española, vol. V, Madrid, Tip. de Revista de Archivos, Bibliotecas y Museos, 1916.

EL CENSOR (1781-1787), Introducción de José F. Montesinos, edición, prólogo y notas de E. García-Pandavenes, Barcelona, Labor, 1972.

CRUZ, Ramón de la, Marta abandonada y Carnaval de París, edición y notas de Felisa Martín Larrauri, prefacio de Emano Caldera, Roma, Bulzoni, (Tramoya, 1), 1984.

Chaves MonToya, Teresa y Fernando Rodríguez de la Flor, «Teatro musical», Historia de la Literatura española. Siglo XVIII (1),vol. 6, Víctor García de la Concha (dir.), Guillermo Carnero (coord.), Madrid, Espasa Calpe, 1995, pp. 372-399.

CHECA Beltrán, José, «Los clásicos en la preceptiva dramática del siglo XVIII», Cuadernos de teatro Clásico, 5 (1990), pp. 13-32.

DíAZ DE ESCOVAR, Nicolás y LASSO DE LA VEGA, Historia del teatro español, 2 vols., Barcelona, Montaner y Sión, 1924.

DíEZ-REgAÑón, José M. ${ }^{a}$, «Una parodia española en Ifigenia en Áulide» Argensola, vol. VIII, 1957, pp. 297-305.

DomíngueZ De LA PAZ, Elisa y Pablo CARRASCOSA Miguel, «El Niño Inocente de la Guardia, de Lope y La viva imagen de Cristo, de Hoz y Cañizares: semejanzas y diferencias», Diálogos Hispánicos de Ámsterdam, n. ${ }^{\circ}$ 8, 1989, vol. II, Ámsterdam, Rodopi, pp. 347-357.

DURÁn, Agustín, Discurso sobre el influjo de la crítica en la decadencia del teatro español, edición de D.L. Shaw, Málaga, Ágora, 1994.

EBERSOLE, Alva V. José de Cañizares, dramaturgo olvidado del siglo XVIII, Madrid, Ínsula, 1975.

FARINELli, Carlo Broschi, Fiestas reales prólogos de Antonio Bonet Correa y Antonio Gallego, Madrid, Turner, 1991. 
FARREL, Anthony A. «¿Imitación o debilitación? La viva imagen de Cristo de José de Cañizares y Juan de la Hoz y Mota», Diálogos Hispánicos de Ámsterdam, vol. II, Ámsterdam, ed. Rodopi, 1989, pp. 359-367.

FEIJOO, Fr. Benito Jerónimo, Obras escogidas, seleccionadas por Agustín Millares Carlo vol. IV, Madrid, Atlas, (Biblioteca de Autores Españoles 143), 1961.

—, Teatro crítico universal, ed. Angel Raimundo Fernández González, Madrid, Cátedra, 1993.

FERNÁNDEZ DE MORATÍN, Leandro, «Discurso histórico sobre los Orígenes del teatro español», Obras de don Nicolás y Leandro Fernández de Moratín, Madrid, Editorial Rivadeneyra (Biblioteca de Autores Españoles 2), 1850, pp. 147-305.

—, «Sátira contra los vicios introducidos en la poesía castellana», Obras de don Nicolás y Leandro Fernández de Moratín, Madrid, Editorial Rivadeneyra (Biblioteca de Autores Españoles 2), 1857, pp. 567-580.

—, «Discurso Preliminar», Obras de don Nicolás y Leandro Fernández de Moratín, Madrid, Editorial Rivadeneyra (Biblioteca de Autores Españoles 3), 1860, pp. 307-325.

FERnÁNDEZ De Moratín, Nicolás, La Petimetra. Desengaños al teatro español. Sátiras, edición, introducción y notas de David T. Gies y Miguel Ángel Lama, Madrid, Castalia, 1996.

FERNÁNDEZ Y GONZÁLEZ, Ángel Raimundo, «Ideas estéticas y juicios críticos del P. Feijoo en torno a la problemática del teatro del siglo XVIII», Boletín de la Biblioteca Menéndez Pelayo, nn. 1-4, 1964, pp. 19-35.

FitZMAURICE-Kelly, James, Historia de la literatura española, Madrid, Librería General de Victoriano Suárez, 1916, $2^{\text {a }}$ ed. correg.

FORNER, Juan Pablo, Exequias de la lengua castellana. Sátira menipea, edición crítica de José Jurado, Madrid, CSIC, 2003.

García de Villanueva Hugalde y PaRRa, Manuel, Origen, épocas y progresos del Teatro español, Madrid, Imp. Gabriel de Sancha, 1802.

GIL DE ZÁRATE, Antonio, Manual de literatura, 2 vols., Madrid, Gaspar y Roig, 1874, $2 .^{\text {a }}$ ed

GLASER, Edward, «Dos comedias españolas sobre El falso Nuncio de Portugal», Estudios hispanos-portugueses. Relaciones literarias del Siglo de Oro, Madrid, Castalia, 1957, pp. 221-265.

Goldman, Peter B., «Plays and their Audiences in the Eighteenth Century: Notes on the Fortunes of a Comedia by Cañizares», Modern Language Studies, vol. XIV, 1984, pp. 53-68.

GUTIÉRREZ DE LOS Ríos y CóRDOBA, Francisco, Conde de Fernán Núñez, El hombre práctico o Discursos varios sobre su conocimiento y enseñanza, Introducción, edición y notas de Jesús Pérez Magallón y Russell P. Sebold, Córdoba, Publicaciones Obra social y cultural Caja Sur, 2000.

HARTZENBUSCH, Juan Eugenio, «Cañizares»Revista Española, de Indias y del extranjero, vol. IV, 1845, pp. 372-402.

—, «Racine y Cañizares», La Ilustración, vol. VII, 1856, pp. 46-47; 62-68.

HERRERA NAVARRO, Jerónimo, Catálogo de autores teatrales del siglo XVIII, Madrid, Fundación Universitaria Española, 1993.

Hurtado, Juan y J. De la Serna y Ángel González Palencia, Historia de la literatura española, Madrid, 1932.

IRIARTE, Tomás de, Los literatos en Cuaresma, edición de Emilio Martínez Mata y Jesús Pérez Magallón, Madrid, Biblioteca Nueva, 2005.

JoHns, Kim L., José de Cañizares. Traditionalist and innovator, Valencia, Albatros, 1981.

LEAL BONMATI, M. a del Rosario, «José de Cañizares y el teatro escénico cortesano (17001724)» Cinta Canterla (ed.): Nación y Constitución: de la Ilustración al Liberalismo. Congreso Internacional organizado por la Sociedad Española de Estudios del Siglo 
XVIII, Sevilla, Sociedad Española de Estudios del siglo XVIII-Universidad Pablo de Olavide-Junta de Andalucía, Consejería de Innovación, Ciencia y Empresa, 2006, pp. 451-476.

Lista Y ARAGÓN, Alberto, «Don José de Cañizares», Ensayos literarios y críticos, Sevi1la, Calvo-Rubio y Compañía, 1844, pp. 211-218.

LoPE, Hans-Joachim, «El Pleyto de Hernán Cortés de José de Cañizares: un drame historique oublié du dix-huitiéme siécle en Espagne», Studies on Voltaire and the 18 Century, Oxford, $\mathrm{n}^{\circ} 265$ (1989) pp. 1446-1350.

LÓPEZ SEDANO, José, Marta aparente, edición, prefacio y notas de Antonieta Calderone, Roma, Bulzoni, (Tramoya 2), 1984.

LuZÁn, Ignacio de, Poética, edición, prólogo y glosario de Russell P. Sebold, Barcelona, Labor, 1977.

MACHADO, Manuel, «La «Niña de la Plata» de Lope, refundida por Cañizares. Contribución al estudio de la censura de teatros en el siglo XVIII», Revista de Bibliotecas, Archivos y Museos, vol. 1, 1924, pp. 36-45.

MACKENZIE, Anna L., «The «Deadly Relationship of Elizabeth I and Mary Queen of Scots dramatized for the Spanish stage: Diamante's La Reina María Estuarda and Cañizares'(?) Lo que va de cetro a cetro y crueldad de Inglaterra», Dieciocho, vol. 9, 1986, pp. 201-218.

MARTín Moreno, Antonio, Historia de la música española. Siglo XVIII, vol. IV, Madrid, Alianza, 1996.

MARTÍNEZ DE LA ROSA, Francisco, «Apéndice sobre la comedia española», Obras de don —, vol. III, Madrid, Atlas, (Biblioteca de Autores Españoles 150), 1962, pp. 175-259

MAYANS Y SISCAR, Gregorio, Obras completas, vol. I y II, edición de Antonio Mestre Sanchís, Valencia, Ayuntamiento de Oliva, Diputación de Valencia, 1984

-, «Oración preliminar de D. en: Saavedra Fajardo, República literaria, Madrid, Compañía Iberoamericana de Publicaciones, Madrid, s.a.

MENÉNDEZ PELAYO, Marcelino, Historia de las ideas estéticas en España, 3 vols., Madrid, CSIC, 1962

MERIMÉE, Paul, L’art dramatique en Espagna dans la première moitié du XVIII siècle, Toulouse, Université de Toulouse-Le Mirail, 1983.

MESONERO Romanos, Ramón, «Dramáticos posteriores a Lope de Vega», 2 vols., Madrid, Imp. Rivadeneyra, (Biblioteca de Autores Españoles 62 y 69), 1859.

NASARRE, Blas de, Disertación o Prólogo de las comedias en España, edición de Jesús Cañas Murillo, Cáceres, Universidad de Extremadura, 1992.

OnRuBia DE MENDOZA, José, El teatro de José de Cañizares, Barcelona, Tesis Universitaria, 1965 (resumen).

PALACIOS HERNÁNDEZ, Emilio, «El teatro en el siglo XVIII (hasta 1808)», Historia del teatro en España, vol. II, Madrid, Taurus, 1988, pp. 57-376.

—, «El teatro barroco español en una carta de Bernardo de Iriarte al Conde de Aranda», Cuadernos de Teatro Clásico, n. 5 (1990), pp. 43-64.

PAUN DE GARCÍA, Susan, "A censor on stage: Cañizares and magic plays», Dieciocho (29.1), 2006, pp. 55-67.

PEDRAZA JimÉnEZ, Felipe y Milagros RoDRÍGUEZ CÁCERES, Manual de literatura española. Siglo XVIII, vol. V, Pamplona, Cénlit Ediciones, 1981.

PELlICER, Casiano, Tratado histórico sobre el origen y progresos de la comedia y del histrionismo en España, Madrid, 1804, edición a cargo de José M. Díez Borque, Barcelona, Labor, 1975 .

PÉREZ MAgallón, Jesús, En torno a las ideas literarias de Mayans, Alicante, Instituto de Cultura «Juan Gil-Albert», Diputación de Alicante, 1991.

—, «El hacerse de un teatro nuevo entre los siglos XVII y XVIII», Dieciocho, Anejos 1 (1997), pp. 131-154

- «Hacia un discurso poético nuevo en el tiempo de los novatores.»Bulletin Hispanique n. 2 (2001): 449-79. 
—, «El tiempo de los novatores (1675-1725), o en la modernidad española.» Laurel 3 (2001): 37-63.

—, «La problemática cultura del tiempo de los novatores (1675-1725).» Salina 15 (2001): 99-112.

-, Construyendo la modernidad: La cultura española en el Tiempo de los Novatores (1675-1725), Madrid, CSIC (Anejos de Revista de Literatura 54), 2002.

—, «Modernidades divergentes: el tiempo de los novatores.» El Fénix de España. Modernidad y cultura propia en la España del siglo XVIII (1737-1766). Ed. Pablo Fernández Albaladejo. Madrid: Marcial Pons ; Universidad Autónoma de Madrid ; Universitat d'Alacant ; Casa de Velázquez, 2006. 43-56.

PozUelo Yvancos, José M. ${ }^{a}$ y Rosa M. ${ }^{a}$ ARADRA, Teoría del canon y Literatura española, Madrid, Cátedra, 2000.

QUINTANA, Manuel José, «Las reglas del drama», Obras completas de don

Madrid, Rivadeneyra, (Biblioteca de Autores Españoles 19), 1852.

RứZ RAMÓN, Francisco, Historia del teatro español: (desde sus orígenes hasta 1900), Madrid, Cátedra, 1983, $5^{\text {a }}$ ed.

RULL, Enrique, «El Picarillo de España de José de Cañizares», La Picaresca. Orígenes, textos y estructuras. Actas del I Congreso Internacional sobre la picaresca organizado por el Patronato Arcipreste de Hita, dir. Manuel Criado de Val, Madrid, Fundación Universitaria Española, 1979, pp. 849-861.

SCHAEFFER, Adolf, Geschichte des Spanischen Nationaldramas, vol. II, Leipzig, Brockhaus, 1890.

SCHACK, Adolf Friederich von, Historia de la literatura y del arte dramático en España, traducido por Eduardo de Mier, 5 vols., Madrid, Imp. M. Tello, 1885.

SCHLEGEL, Friederich, Obras selectas, edición, introducción y notas de Hans Juretsche, traducción de Miguel Ángel Vega Cernuda, 2 vols., Madrid, Fundación Universitaria Española, 1983.

SHERGOLD, N. D y John E. VAREY, Teatros y Comedias en Madrid: 1687-1699. Estudio y documentos. London, Tamesis Books, (Tamesis, Serie C, Fuentes para la Historia del Teatro en España VI), 1979.

-, Comedias en Madrid: 1603-1709. Repertorio y estudio bibliográfico, London, Tamesis Books (Tamesis, Serie C, Fuentes para la Historia del Teatro en España IX), 1989

TICKNOR, George, Historia de la literatura española, traducida al castellano con adiciones y notas críticas de Pascual de Gayangos y Enrique de Vedia, Madrid, Imprenta de la Publicidad, 1851-1856.

TRÍFILO, Samuel A. «Influencias calderonianas en el drama de Zamora y Cañizares», Hispanófila, vol. IV (1961), pp. 38-46.

VALBUENa PRAT, Ángel, Historia de la literatura española, vol. III, Barcelona, 1950.

VALLEJO GONZÁLEZ, Irene, «Complejidad y espectacularidad en «La más amada de Cristo, santa Gertrudis, la Magna» de Cañizares», El Siglo que llaman Ilustrado. Homenaje a Francisco Aguilar Piñal, coordinado por Joaquín Álvarez Barrientos y José Checa Beltrán, Madrid, CSIC, 1996, pp. 875-881.

VITSE, Marc, Elements pour une theorie du théatre espagnol du XVII siècle, Toulouse, Université de Toulouse-Le Mirail, 1988.

—, «Tradición y modernidad en «El dómine Lucas» de José de Cañizares», Coloquio internacional sobre el teatro español del siglo XVIII, Abano Terme, Piovan, 1988, pp. 383-397.

Fecha de recepción: 31 de enero de 2007

Fecha de aceptación: 26 de julio de 2007 